July 2021

\title{
The Huawei Moment
}

CSET Policy Brief

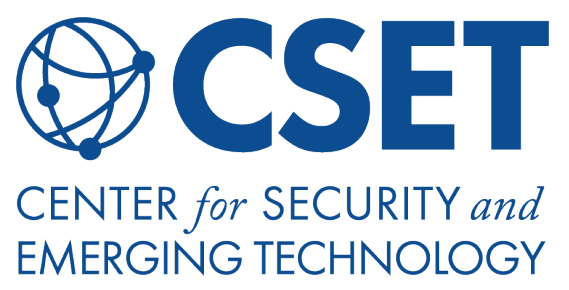

AUTHORS

Alex Rubin

Alan Omar Loera Martinez

Jake Dow

Anna Puglisi 


\section{Executive Summary}

5G hardware will become the backbone of the United States', and most of the world's, telecommunications infrastructure. As such, it is a foundational element of U.S. national security. Despite the U.S. lead in telecommunications throughout the twentieth century, it now finds itself at the precipice of deploying a new generation of technology for its critical communications foundation without a U.S. company capable of providing a secure end to end solution. The United States is forced to choose whether to accept the economic costs of delaying deployment of a new generation of communications technology or instead run the security risks of choosing the market leader, Chinese firm Huawei. ${ }^{1}$

How did Washington, at the beginning of the twenty-first century, not take action to prevent a geopolitical competitor from taking leadership in telecommunications, a key piece of national security relevant critical infrastructure? Strategic investments and support by the U.S. government facilitated U.S. telecommunications equipment firms, AT\&T prime among them, to lead the field and develop world-changing technological innovations that spurred the creation of new sectors. ${ }^{2}$

However, over time, U.S. firms lost their market leader positions. The exact causes have been debated, but contributing factors are generally thought to include antitrust pressures from the U.S.

Department of Justice to break apart a regulated monopoly, along with fundamental changes in how U.S. corporations operate. The bigger problem is that the U.S. government failed to monitor the decline of U.S. leadership in a critical national security infrastructure area and when national security concerns were raised about this, did not use the tools available to the government to attempt to alter the situation.

Many factors inhibited the types of long-term investments necessary for sustained competitiveness and innovation in the telecommunications industry. Among them include changing perceptions in Washington about industrial policy. ${ }^{3}$ The U.S. private sector's prioritization of short-term profits, inhibited the 
type of research and development (R\&D) investments that were necessary for preserving overall competitiveness and innovation in telecommunications hardware-which Huawei has developedthat is defined by generational updates that occur over 10 to 15 years. ${ }^{4}$

In contrast, the Chinese government made advanced telecommunications a national priority and provided a variety of support to a new entrant in the telecommunications equipment industry, Huawei. ${ }^{5}$ Buoyed by R\&D subsidies, export financing, diplomatic support, and a guaranteed market, Huawei progressively grew its market share overseas and devoted significant investments to R\&D. It moved from being largely a provider of low-end equipment to emerging markets to being the world leader in the next generation of wireless networks. ${ }^{6}$

Chinese government support for Huawei goes far beyond traditional industrial policies seen in Europe and Asia. It is comprehensive and represents an alternative blueprint for the development of other emerging technologies and industries. It also highlights the limitations of relying on market-driven development for key technologies when a strategic competitor has made development of that technology a national strategic goal. ${ }^{7}$

The juxtaposition of the U.S. telecommunications hardware industry's progressive decline and Huawei's rise during the same period of roughly three decades highlights the necessity of government support for strategic industries. This is particularly true when private profits do not align with national interests-as was the case in telecommunications equipment. ${ }^{8}$ The $5 \mathrm{G}$ case study also provides a cautionary tale for additional strategic emerging industries - such as Al, biotechnology, and clean energy. These industries might succumb to similar market failures if there is no support for the foundational research, facilities, and talent development that support them over the long-term. This may be the case especially when nascent research and companies are forced to compete with strategic competitors backed by a nationstate. 
The characteristics of 5G-small profit margins and longtime horizons-have broader applicability to other technologies that, without efforts to adjust the market incentives, are likely to succumb to similar predicaments for the United States. ${ }^{9}$ As Washington discusses how best to support development efforts in emerging technologies, this study argues for a focus on those national security relevant technologies that are most at risk of foreign adversarial competition-not only military related technology. This involves increased investments and strategic planning that builds robust private-public partnerships, and supports the development of key enabling technology, infrastructure, and human capital. ${ }^{10}$ The United States has tools it can use-both carrots and sticks - to support a proactive approach to supporting key areas of development with national security implications. Tools that the United States has used in the past successfully to promote technology development and that could be used again include:

R\&D Funding: While the percentage of government funding has shrunk over the past decades, it still provides a key piece of the national innovation base that is not prioritized by the private sector. U.S. government funding provides foundational discoveries that feed into both commercial and military developments. ${ }^{11}$

Corporate Tax Incentives: Washington has used its tax code to incentivize R\&D investments by allowing startups and small businesses to qualify for limited tax credits. ${ }^{12}$

Public Procurement: The U.S. government has used the power of federal procurement dollars to promote the development of nascent industries and help them reach economies of scale and commercialize their products. ${ }^{13}$

Talent Development: The U.S. government has supported the education of human capital to bolster technology development efforts. ${ }^{14}$

Tech Alliances: The U.S. government has signed collaborative agreements with like-minded countries to build tech alliances in strategic areas. ${ }^{15}$ 
Export Financing: The United States has provided strategic financial support for foreign firms to purchase goods from U.S. companies that are key players in the U.S. economy, providers of goods to the U.S. military, or support U.S. foreign policy objectives. ${ }^{16}$ 


\section{Scope Note}

This paper is focused on the factors that allowed Chinese firm Huawei to become the global leader in $5 \mathrm{G}$ equipment before the United States launched its pressure campaign in 2018. We acknowledge that the campaign has caused Huawei significant economic and technological challenges, including its mobile handset business. However, regardless of these efforts, the firm was still able to achieve market leadership by leveraging Chinese government support and benefitted from a lack of U.S. government attention to technological competition with China prior to 2018. Even with the U.S. lead in chips and software, Huawei's market position is troublesome for the United States and its allies. Going forward, this will be one of the biggest policy challenges. How do the United States and its like-minded allies construct policies for the development of emerging technologies that adhere to global norms and the values of market-driven competition, while protecting these nascent industries from a global actor that does not and seeks to exploit the global system to its own benefit? This "Huawei Moment" can be the catalyst to ensure that the United States and its allies are prepared for this kind of global competition and design policies that reaffirm that technology is indeed a key part of national security. 


\section{Table of Contents}

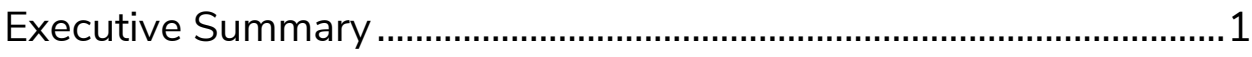

Scope Note

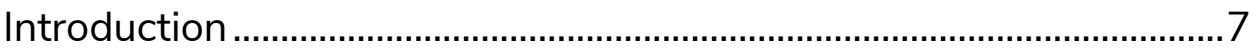

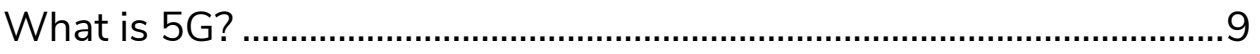

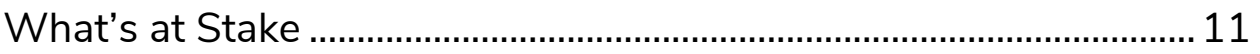

U.S. Government Support for the Telecommunications

Industry in the Twentieth Century ....................................................... 12

Case Study-Strategic Chips: U.S. Government Support for the Semiconductor Industry ............................................................ 15

Why Didn't the United States Develop 5G Hardware? ................... 17

Collapse of the U.S. Telecommunications Equipment Industry, 1990s-2018 ................................................................. 17

Losing the Foundation: Lack of U.S. Government Action.............. 19

Private Companies Chose Profit Over Strategic

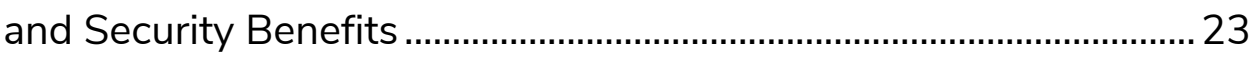

Hollowing Out of Corporate R\&D .................................................. 23

The Huawei-China Success Story: From Small Beginnings to Global Powerhouse: The Power of National Champions ............ 28

Chinese Government Support............................................................. 31

Intellectual Property Theft .................................................................. 34

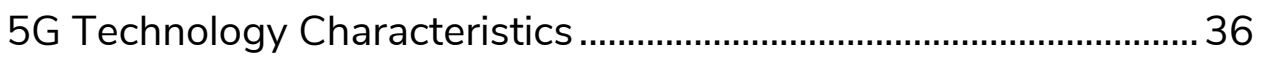

Historically-Deployed Technology Development Tools .................... 37

Lessons from the Huawei Moment....................................................... 39

Strategic Priority for the Chinese Government............................... 39

Use All Facets of China's S\&T Infrastructure ................................... 40

Promise of the China Market............................................................ 40

Plausible Deniability ............................................................................... 40

Build Capacity for the Future ....................................................... 41

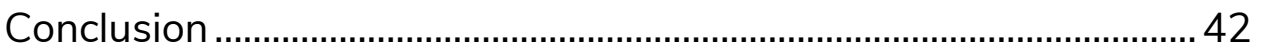

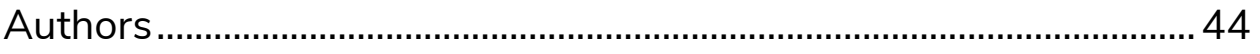

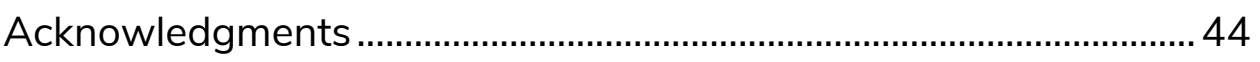

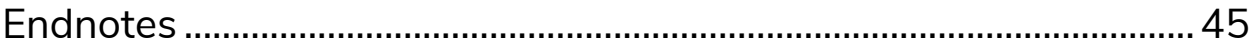




\section{Introduction}

$5 G$ is a key part of national security critical infrastructure, and will represent a big change over $4 \mathrm{G}$ capabilities, as well as potentially support advancements in many other sectors, including remote medicine, advanced manufacturing, autonomous vehicles, banking, energy, and the Internet of Things. ${ }^{17}$ However, the United States finds itself without a trusted supplier of $5 G$ hardware, leaving its companies the option of replacing existing equipment with trusted older generation equipment (4G), which would delay the eventual $5 \mathrm{G}$ transition. Alternatively, U.S. companies could replace existing equipment with untrusted Huawei equipment, which would leave critical national security communications infrastructure vulnerable to a non-friendly foreign nation-a situation the United States has not previously found itself in. ${ }^{18}$

Figure 1: $5 G$ vs. 4G Networks

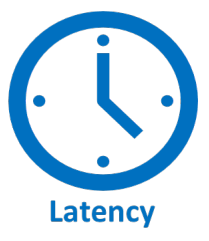

$5 \mathrm{G}:<1 \mathrm{~ms}$

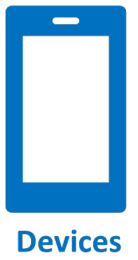

5G: $\leq 1 \mathrm{million} / \mathrm{km}^{2}$ 4G: $100,000 / \mathrm{km}^{2}$
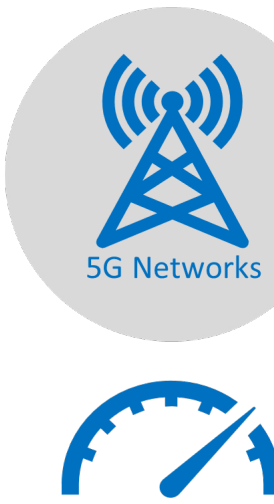

Speed

5G: $\leq 10 \mathrm{Gbps}$

4G: $300 \mathrm{Mbps}$

Source: DigitalTrends and Samsung Mobile Press. ${ }^{19}$ 
This policy brief will discuss how the United States, today, finds itself in the situation where the primary provider of critical national security infrastructure-communications technology-is a strategic competitor and will identify policy options for what the United States might do in the future to prevent this for other essential national security infrastructure and emerging technologies.

The United States can no longer take for granted its undisputed position as the global technology leader. By analyzing China's development of a $5 \mathrm{G}$ technology champion, this policy brief will highlight the challenges that a centralized and well-funded system poses to free and open market economies. Huawei's market dominance and role in key partner countries will pose a growing and novel risk for the United States. Many countries are faced with a difficult choice; build on the existing Huawei $4 \mathrm{G}$ network infrastructure despite the potential security risks, or accept the costs of replacing this infrastructure and building $5 \mathrm{G}$ networks with equipment from Nokia or Ericsson, that is, in most cases, more expensive and less technologically advanced. ${ }^{20}$

Figure 2: Selected Applications of 5G

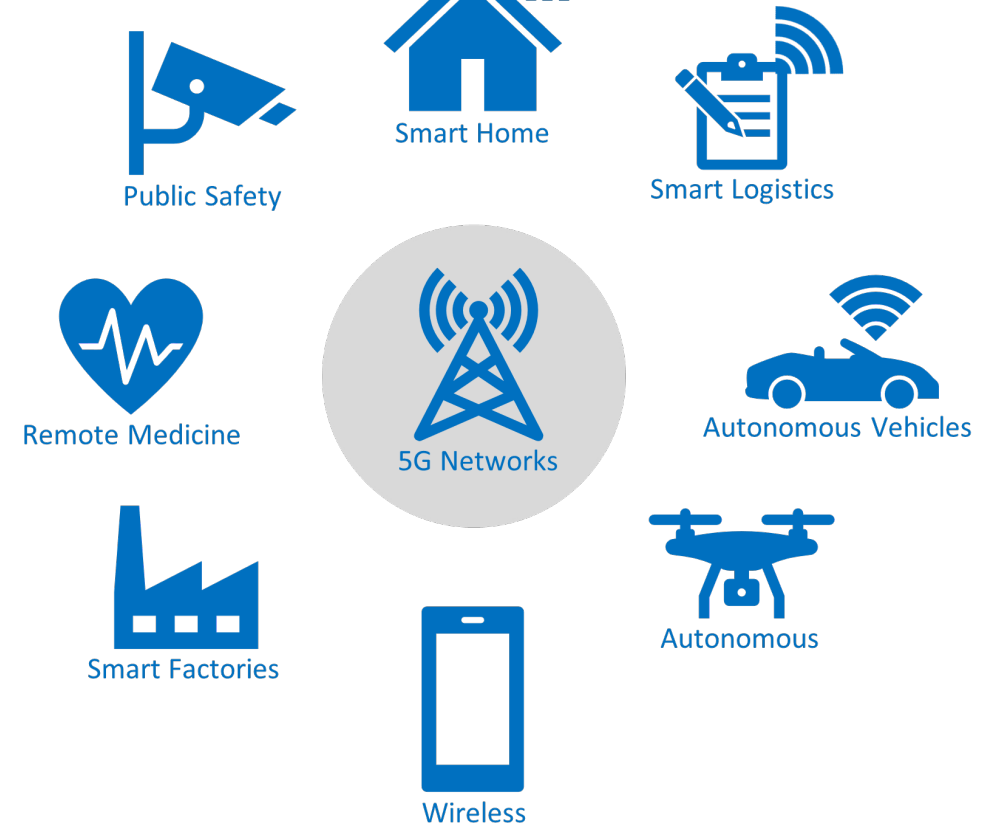

Source: DigitalTrends. ${ }^{21}$

Center for Security and Emerging Technology $\mid 8$ 


\section{What is $5 G$ ?}

$5 \mathrm{G}$ is the next generation in wireless communications that stands to dramatically improve the speed, connectivity, and reliability of existing networks. ${ }^{22} 5 \mathrm{G}$ networks will largely be built on top of the existing 4G infrastructure, deliver new tools and services, and expand the mobile ecosystem into new industries. ${ }^{23} 5 \mathrm{G}$ will enable more devices to connect to wireless networks, allowing new kinds of devices to become integrated, ranging from appliances to vehicles. ${ }^{24}$

Huawei's market dominance of $5 \mathrm{G}$ network equipment-being the only provider capable of providing an end-to-end solutionpresents a series of security risks for the United States, beyond the already much discussed potential for cyber espionage, such as the weaponization of network availability. Former Senior Director for Cyber Operations for the National Security Council staff, Thomas Donahue, claimed that "availability is a greater problem than espionage, as any communications that run on Chinese-owned networks would be subject to disruption" in a large-scale crisis scenario. ${ }^{25}$ Former Director of National Intelligence, Daniel Coats, highlighted in the 2019 Worldwide Threat Assessment that weaponization could come through a denial of network service during a crisis. ${ }^{26}$ The Defense Innovation Board in 2019 highlighted a scenario wherein Chinese firms become increasingly dominant, leading to a "declining set of vendors that would serve the US market. These vendors [would] in turn be unable to invest R\&D towards future telecommunications equipment offerings due to decreasing market share, limiting the number of competitive products and depriving the [US Department of Defense] and US industries of better and cheaper global supply chains."27

The U.S. government-awakening to the security implications of a Chinese company with close ties to the Chinese government emerging as the global leader in advanced telecommunications equipment-has also led an effort to prevent Huawei from winning $5 G$ contracts worldwide and has partnered with private technology firms and like-minded governments to develop secure 5G alternatives. ${ }^{28}$ Policymakers have increasingly targeted Huawei's supply chain. In 2019, the U.S. Department of Commerce added 
Huawei to its Entity List, prohibiting U.S. companies from supplying the firm with certain controlled items. ${ }^{29}$ Washington has subsequently bolstered the initial export restrictions, most recently prohibiting any firm, U.S. or foreign, that uses U.S. semiconductor manufacturing equipment from providing any chips to Huawei. ${ }^{30}$

What China has done with $5 \mathrm{G}$ is an example of how China pursues technologies that are critical foundational elements of the modern world. China uses its instruments of national power to position its companies in leading roles in critical technology niches, such as the next generation of communications infrastructure. China does this because it recognizes the many economic and security benefits these sectors will produce. Ensuring a secure $5 \mathrm{G}$ rollout is expected to be critical for future generations of mobile networks as $5 \mathrm{G}$ infrastructure, like previous generations (e.g., 4G, 3G, etc.), will form the foundation of future network generations (e.g., 6G, 7G, etc.). Leadership in deploying and supplying this technology will enable China to seize first mover advantages in 5G-enabled services and technologies and secure the broader economic and strategic benefits of being the key supplier for this critical infrastructure. ${ }^{31}$ 


\section{What's at Stake}

To fully understand the myriad benefits of 5G, it is useful to quickly illustrate the benefits that U.S. wireless operators' leadership in the 4G rollout provided to the U.S. economy. A 2018 study by Recon Analytics found that U.S. leadership in the $4 \mathrm{G}$ transition accounted for nearly $\$ 100$ billion of the increase in annual GDP by 2016 , increased total wireless-related jobs by 84 percent from 2011 to 2014 , and led to approximately $\$ 125$ billion in revenue to U.S. companies and more than $\$ 40$ billion in additional app store revenue-money which could have gone elsewhere had the U.S. not led the $4 \mathrm{G}$ rollout. ${ }^{32}$

Business analytics firm IHS Markit found that $5 \mathrm{G}$ has the potential to unlock up to $\$ 12.3$ trillion of revenue across a broad range of industries, with a large share of that revenue probably flowing to the firms and countries that lead the transition. ${ }^{33}$ Researchers also expect that the $5 \mathrm{G}$ global value chain will grow output to $\$ 3.5$ trillion in 2035 and support approximately 22 million jobs globally-larger than the entire mobile value chain today-with the largest share flowing to China. ${ }^{34}$ 


\section{U.S. Government Support for the Telecommunications Industry in the Twentieth Century}

Support for strategic infrastructure and industries-through traditional industrial policies, regulated competition, and federal procurement-has a long history in the United States. ${ }^{35}$ In previous generations, the telecommunications sector had overlapping priorities with the U.S. government. In 1913, the U.S. government reached an agreement with AT\&T that allowed the firm to operate as a monopoly for most of the twentieth century and roll out a nationwide short- and long-distance calling network. ${ }^{36}$ The Bell System (Ma Bell as it was known) encompassed all aspects of the telecommunications sector and allowed its R\&D arm, Bell Labs, to develop numerous paradigm shifting technologies and discoveries, including the transistor, satellite communications, lasers, communications theory, and cellular communications. ${ }^{37}$

Ma Bell was composed of four key components. The first, AT\&T, operated the system's long-distance calling network, ensuring uniformity and compatibility between different local networks. ${ }^{38}$ The second, the regional operating companies, operated the shortdistance calling network and facilitated communications within cities. ${ }^{39}$ The third, Western Electric, manufactured the equipment used in the Bell System, including phones, switching devices, and telephone cables. ${ }^{40}$ The fourth, Bell Labs, was the system's inhouse R\&D arm that sought to constantly improve the telephone system. ${ }^{41}$

Jon Gertner's Idea Factory highlights some of the key advantages that allowed Bell Labs to thrive: long development timelines, constant funding and multidisciplinary environment. ${ }^{* 42}$ The consistent funding provided by the guaranteed revenue from the regional phone companies and AT\&T ensured that the Labs could invest in projects with long time horizons and could accept high

\footnotetext{
* Co-locating scientists from different disciplines with researchers and developers has been flagged as a key characteristic of building an innovation foundation according to Mervin Kelly, Bell Labs executive and president from 1925 to 1959.
} 
degrees of risk without concern that failure would lead to the Labs' dissolution. ${ }^{43}$

Figure 3: The Bell System

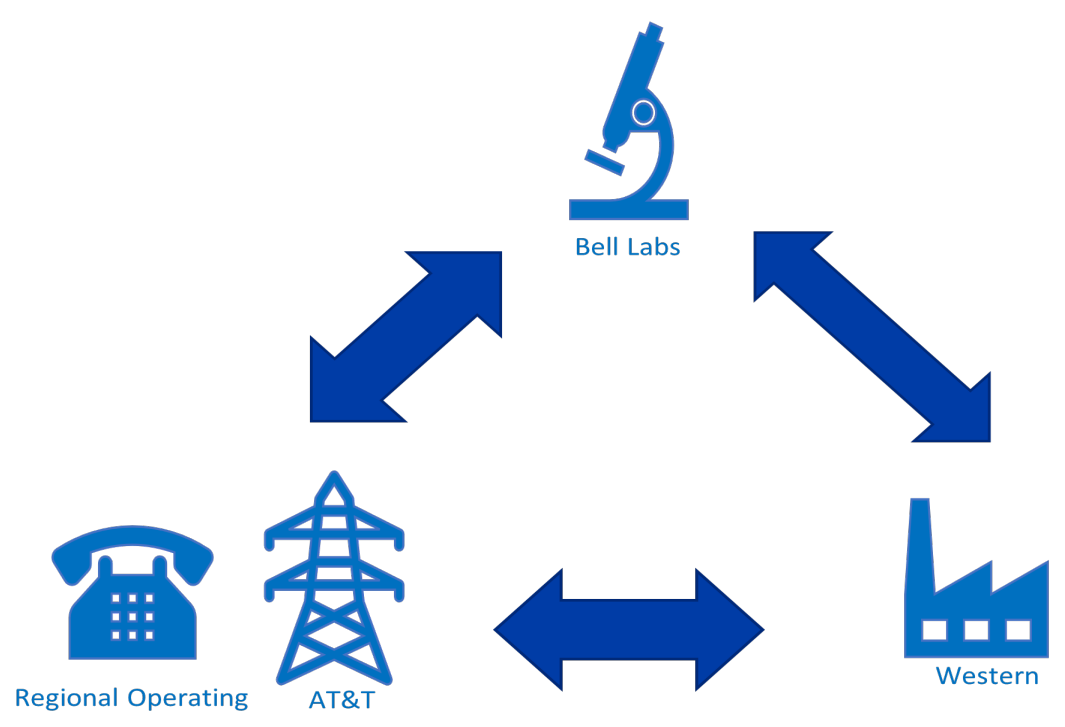

Source: The Idea Factory by Jon Gertner. ${ }^{44}$

The Labs also succeeded because they had a critical mass of the "best people" who were located close together so they could collaborate on interdisciplinary projects. ${ }^{45}$ Beyond funding, the Labs provided their researchers with the tools they needed to do the work and, most importantly, a guaranteed market for the products they developed; creating a direct connection between research, product development, manufacturing, and commercialization. ${ }^{46}$

The Labs benefitted from a constant supply of problem sets provided by the telephone system, spurring researchers to seek new technologies or methods to improve the system. ${ }^{47}$ Similarly, researchers could directly see the improvement their developments or discoveries created, providing an essential connection between research, development, and implementation. ${ }^{48}$ Finally, the ties between the Labs and the system's manufacturing arm, Western Electric, ensured that in many cases even the most theoretical researchers placed a premium on the real-world applicability and usability of their work. ${ }^{49}$ For example, Morris Tanenbaum 
reportedly noted on the night he invented the silicon transistor that it was a technology that could easily be manufactured..$^{50}$

Beyond the indirect support the U.S. government provided to $\mathrm{Ma}$ Bell through the granting of a monopoly, federal dollars directly facilitated the emergence of the modern semiconductor industry, a key enabler of modern telecommunications as well as almost every modern technology. ${ }^{51}$ The U.S. Air Force and NASA were the first customers of the nascent U.S. semiconductor firms for their Minuteman II and Apollo programs during the 1960s. ${ }^{52}$ Similarly, after seeing the early U.S. advantage in the industry slip away to Japanese competitors, the U.S. Defense Department launched the Strategic Computing Initiative, which allocated over \$1 billion to support semiconductor R\&D between 1983 and 1993. ${ }^{53}$ 
Case Study-Strategic Chips: U.S. Government Support for the Semiconductor Industry

In 1958, Texas Instruments discovered how to manufacture integrated circuits (ICS) by making each transistor in a circuit out of a single piece of material, a process later improved upon by Fairchild Semiconductor. ${ }^{54}$ Despite the promise of this improvement in the manufacturing process, the cost to produce an individual IC was too high to make them accessible to the broader commercial market. ${ }^{55}$ Federal procurement under the Eisenhower and Kennedy administrations were crucial in supporting the industry's efforts to lower costs and commercialize their products. ${ }^{56}$ The U.S. Air Force was the first to procure large orders of ICs for its Minuteman II missile program, building the semiconductor industry virtually overnight as demand jumped to thousands of chips per week. ${ }^{57}$ Similarly, during the 1960 s, NASA procured enough chips for its Saturn $\vee$ rocket and the Apollo Program to drive the price of a specialized chip down from $\$ 1,000$ to between $\$ 20$ and $\$ 30$ in a few years. ${ }^{58}$ More broadly, the expanding military and space demand for ICs allowed the industry to lower the price of its commercial offerings from about $\$ 50$ per unit in 1962 to $\$ 2.33$ per unit by 1968 , drastically improving the industry's commercial viability. ${ }^{59}$

Helped by government procurement, the nascent semiconductor industry expanded into more commercial markets, driving the government's share of the market from a high of about 70 percent of sales in the mid-1960s to about 10 percent by the 1980 s. $^{60}$ During this time, similarly aided by government support and industrial policies, Japan's semiconductor firms surged in manufacturing technology and began to outpace U.S. competitors. ${ }^{61}$ Concerned by this possibility, the U.S. Defense Department launched its Strategic Computing Initiative in 1983 to funnel significant financial support to U.S. firms. ${ }^{62}$ In 1987, the U.S. government joined with 14 domestic semiconductor manufacturers to form a consortium named SEMATECH which stands for "Semiconductor Manufacturing Technology," to regain the U.S. share of the IC market. ${ }^{63}$ Despite ongoing analysis on the precise contributions that SEMATECH and other related efforts made to 
U.S. industry, by the end of the decade U.S. design firms were secure in their global leadership. ${ }^{64}$ While there is debate as to whether this was "effective" and whether it achieved all of its goals, (which depends on how the goals are interpreted and effectiveness is measured), it illustrates what the government can do to attempt to reverse an unfavorable situation. The semiconductor industry has remained a key pillar of U.S. technological, economic, and diplomatic strength, as evidenced by the use of export controls on this technology to target Huawei and other Chinese technology firms. ${ }^{65}$ 


\section{Why Didn't the United States Develop 5G Hardware?}

To fully understand how the United States now finds itself without a domestic $5 \mathrm{G}$ producer it is useful to explore the historical survey of the U.S. telecommunications industry with the mounting antitrust pressure on AT\&T, culminating in the mid-1990s. The commercial sector may not always deliver technologies or services that are critical to national security so it is important for government to monitor its equities in those sectors over time and monitor trends that may have unfavorable implications for national security critical infrastructure.

\section{Collapse of the U.S. Telecommunications Equipment Industry,} 1990s-2018

In 1982, the U.S. Department of Justice and AT\&T agreed to a "consent decree" whereby the firm would spin off its local telephone business into seven regional Bell operating companies (RBOCs). ${ }^{66}$ The breakup of AT\&T had both positive and negative consequences for the U.S. telecommunications business, including increased competition among wireless service providers. However, a key unfortunate outcome-which was probably not foreseen at the time-was the loss of significant corporate research investment and programs. ${ }^{67}$

By the mid-1990s, AT\&T's management decided to spin off its manufacturing arm, Western Electric, to better allow it to sell to the new RBOCs, which were competing with AT\&T for local phone service. ${ }^{68}$ In 1995, Lucent Technologies was formed-and took the majority of Bell Labs' research personnel and programs-and by 1999, had grown to become the world's largest telecommunications equipment firm. ${ }^{69}$

Following a drop in telecom equipment sales in 2000, Lucent's revenue quickly fell, eventually falling into losses in 2001 and 2002. ${ }^{70}$ Despite a rebound in the telecom equipment market in 2004, Lucent struggled to compete with other companies, notably the upstart Huawei, which was receiving subsidies from the Chinese government and benefitted from market access restrictions imposed by the Chinese government. ${ }^{71}$ Finally, in 2006, 
Lucent merged with French telecom firm Alcatel. ${ }^{72}$ Eventually, Alcatel suffered similar drops in its value and in 2015 was acquired by Finnish telecom giant Nokia. ${ }^{73}$

A key reason Lucent was unable to fully take advantage of the telecom market's rebound from 2003 to 2004 was the divestiture of Lucent's enterprise networks division as Avaya in 2001 and its microelectronics division as Agere in 2001, leaving Lucent lacking in critical growth capabilities. ${ }^{74}$ Additionally, beginning in 2001 Lucent began to reduce its R\&D expenditures from an average high of $\$ 5$ billion from 1998 to 2000 to an average low of $\$ 1.2$ billion from 2004 to $2006 .{ }^{75}$ This drop in R\&D expenditure left the firm without significant groundwork with which to support product development. ${ }^{76}$ This illustrates the importance of the role that low and medium tech plays in revenue structure and how competitors benefitting from government subsidies can create market distortions that have big impacts on existing companies. Losing market share in low to medium technology areas reduces the revenue available for firms to reinvest in $R \& D$ for cutting-edge and next generation technology.

The breakup of AT\&T was motivated primarily by a drive to improve consumer protections but, as the above highlighted, weakened the institutional foundation for robust R\&D in the U.S. telecommunications industry. ${ }^{77}$ The industry faltered in the long run-despite an initial burst of activity, growth, and innovationwithout any significant investment from the U.S. government to replace the lost support of the broken up monopoly. ${ }^{78}$ The government effort to breakup AT\&T in the name of consumer protection did not, as the above history indicates, consider the potential national or economic security implications, including the impact of industry R\&D and that innovation would not be maintained for a critical infrastructure technology. Additionally, the national and economic security implications following the dissolution of a monopoly can change over time, such as is illustrated by Lucent's initial profitability and success followed by a steep decline. ${ }^{79}$ This illustrates the importance of government actions and policies that take a holistic approach to technology development and the companies involved. In addition, this also highlights the importance for the government to continue to 
monitor the national security consequences of such actions and policies. In this situation, even if the monopoly was not broken up, the United States' entire critical national security communications technology was dependent on one company and would still have warranted continued government monitoring.

Nortel, a Canadian telecommunication equipment firm, was established by AT\&T's Western Electric to serve the Canadian market. ${ }^{80}$ Western was similarly forced to sell the firm to Bell Canada following Justice Department pressure and by 1999 it had become the second largest telecommunications equipment provider. ${ }^{81}$ Similar to Lucent, Nortel's value dropped significantly by $2002 .{ }^{82}$ The firm struggled to compete with foreign firms, including Huawei, and closed in 2008. ${ }^{83}$

Nortel, following its market peak in 1999, succumbed to the larger trends in the telecommunications equipment market, stymied by poor management and institutional incentives that prioritized short-term gains and individual wealth creation over long-term growth. ${ }^{84}$ Nortel's accounting practices, which presented significant financial irregularities, left analysts unable to fully trust Nortel's reported numbers, which in many cases presented a more optimistic picture than the reality. ${ }^{85}$

The third major North American player was International Telephone and Telegraph. ${ }^{86}$ Following antitrust pressure, AT\&T sold its international business to ITT in 1925 and by 1972, ITT accounted for 60 percent of the French market, dominated in the United Kingdom, and had a monopoly in Spain. ${ }^{87}$ Despite success in international telecommunications equipment sales, the firm acquired large amounts of debt following the 1950s as part of efforts to merge with other firms and enter new markets. ${ }^{88}$ In 1986, ITT sold its telecom equipment business to French Alcatel, the same firm that ultimately purchased Lucent. ${ }^{89}$

\section{Losing the Foundation: Lack of U.S. Government Action}

The relatively quick decline of U.S. telecommunications equipment firms raises a key question: after nearly a century of active promotion of a domestic telecommunications industry, why did the 
U.S. government allow a key sector of significant national security importance to collapse during the first two decades of the twentyfirst century? A study conducted by Jake Dow at the University of Cambridge concludes that U.S. strategic assumptions about the specific threat or non-threat posed by China and the United States' relative lack of emphasis on national competitiveness in emerging technologies as a security priority were the key determinants for U.S. policy during this period. ${ }^{90}$

From the early 2000s to the mid-2010s, the United States prioritized stability in its bilateral relationship with China by bolstering economic cooperation, minimizing areas of disagreement-particularly on security issues - and further incorporating China into the international system. ${ }^{91}$ Washington emphasized incentivizing China to play a "responsible" role internationally and held a deep-seated belief that economic interconnectedness would advance these outcomes. ${ }^{92}$ Within this context of cooperation over competition, any moves to challenge China's dominance of a commercial technology like telecommunications hardware were completely at odds with the broader strategic approach. ${ }^{93}$

Similarly, during this period, the U.S. government treated competition over strategic sectors and technologies as a peripheral national security priority. Even among policymakers focused on the rising China threat, most of the attention was directed toward traditional security issues like military modernization and territorial disputes in the South China Sea. ${ }^{94}$

The U.S. government did not actively monitor the national security consequences of private sector developments in the communication sector. Without clear warnings, it never took concerted strategic action.

This lack of prioritization on strategic technological competition in Washington limited the focus on, and policy response to, threatening developments in the telecommunications sector. The few examples of engagement on this issue, most notably the 2012 investigation into the business practices of Huawei, show how the telecommunications security challenge was known but consigned 
to the margins. Policymakers stopped short from engaging in proactive steps to strengthen U.S. or allied nations' telecommunications firms to compete with the rising challenge from Huawei. ${ }^{95}$ Only as the broader issue of strategic economic and technological competition with China quickly became recognized as a leading national security issue around 2016-17, did China's accelerating dominance in telecommunications equipment receive sustained attention and significant policy responses. ${ }^{96}$

Structural issues also inhibited a strong federal response to China's rise and concurrent U.S. weakness in the telecommunications equipment sector. A stovepiped narrow view of what constitutes national security and the division of responsibility between economic and security-focused organizations inhibited the coordination on policy towards what is both an economic and security issue..$^{97^{*}}$

Perceptions among policymakers that effectively countering Huawei would require the United States to adopt industrial policylike actions, steps that were diametrically opposed to the U.S. political-economic system. ${ }^{98}$ The study quotes a former National Security Council official as saying in May 2020 that countering Huawei would have "depended on some type of industrial policy that was so anathematic" to many in power, that key policymakers did not view economics as mixing with national security. ${ }^{99}$

However, in 2006, the National Research Council (NRC) raised the alarm about U.S. weakness in telecommunications, identifying a security risk as adversaries continue "to pursue strategies that exploit perceived U.S. weakness in telecoms." ${ }^{100}$ China, and Huawei specifically, it outlined as a growing threat in the sector. ${ }^{101}$ The report noted:

The United States will increasingly be forced to purchase technology and services from foreign sources. Several risks are evident: (1) U.S. dependence on foreign sources to meet critical

\footnotetext{
* We recognize that this perspective shifted from 2017 on and as per the scope note has had an impact on Huawei's ability to operate.
} 
defense needs; (2) loss of exclusive or early access to state-of-theart communications technology; (3) loss of know-how to employ state-of-the-art technology; (4) opportunities for other nations to introduce security holes into equipment and networks; and (5) loss of technical capability for cyber defense, vulnerabilities that might be designed into highly complex and sensitive communications systems that could be used or compromised later or in a time of war. ${ }^{102}$

Despite the recommendations from the report, there was no National Security Council or Office of Science and Technology Policy coordinated response to the NRC report-which was the first clear "wake up call" on this problem. This is indeed a case where the government at the highest levels, from a completely reputable, expert, unbiased source received what was essentially a flashing red light that an entire critical infrastructure was at risk. ${ }^{103}$ 


\section{Private Companies Chose Profit Over Strategic and}

Security Benefits

Why did the private sector not prioritize telecommunications equipment and therefore mitigate the aforementioned structural problems in federal policy? U.S. technology firms focused on more profitable business lines while Huawei benefitted from Chinese government support which helped China meet its strategic goal of becoming a leader in telecommunications equipment. ${ }^{104} \mathrm{~A}$ key driver for many of the $4 \mathrm{G}$-enabled sectors in which U.S. technology firms are global leaders, such as video streaming, cloud services, app development, and social media, operate with large profit margins, allowing those firms to consistently top the charts of the most valuable global firms. ${ }^{105}$ As of 2020 , seven of the 10 most valuable companies were internet or software firms, including U.S. firms Alphabet, Amazon, Apple, Facebook, and Microsoft. ${ }^{106}$

However, telecommunications equipment firms generally operate under smaller profit margins than software firms, for which large market share and economies of scale are key to profitability-in 2020, Huawei's, Nokia's, and Ericsson's profit margins were approximately 8,3 , and 6 percent, respectively, compared to margins for the above software firms ranging from 42 to 21 percent. ${ }^{107}$ Additionally, as will be described in the next section, Huawei was able to remain profitable while spending large amounts on R\&D and providing equipment at competitive prices by leveraging Chinese government subsidies and export financing. ${ }^{108}$

\section{Hollowing Out of Corporate R\&D}

Even without U.S. government direction or support for the development of a U.S. 5G champion, why didn't the private sector develop the technology on its own? As the previous section described, U.S. telecommunications developments during the twentieth century were led by private development efforts, albeit with government support. However, following the dissolution of the Bell System and the decline of Bell Labs, U.S. private sector $R \& D$ in the telecommunications sector progressively declined. Corporate labs during the twentieth century, like Bell Labs, were crucial for combining the basic research-usually the remit of 
academia - with the commercial drivers of industry. Researchers at Bell Labs, like at many other corporate labs of the previous century, were cognizant of the connections between foundational research, applied research, product development, and commercialization and manufacturing. ${ }^{109}$ This highlights that not all of the value of these corporate labs can be boiled down to return on investment and profit, but the overall impact that they had on U.S. innovation as the engines of creativity.

From 1981 to 2019, the most recent year for which data is available, the U.S. government's share of total R\&D spending fell from approximately 48 percent to 21 percent. The percentage of total R\&D spending on basic and applied research during this period remained largely consistent, around the 15 percent and 20 percent levels, respectively. Government's R\&D spending is crucial because it tends to be more risk tolerant, longer-term, and is used in basic research to fund scientific advances that lay the foundation for future technological improvements. In contrast, corporate R\&D expenditures, including private venture capital, tend to focus more on later-stage development, which, while important, does not generally lead to technological leaps or breakthroughs that create new industries.

Figure 4: R\&D Spending by Selected Telecom Firms

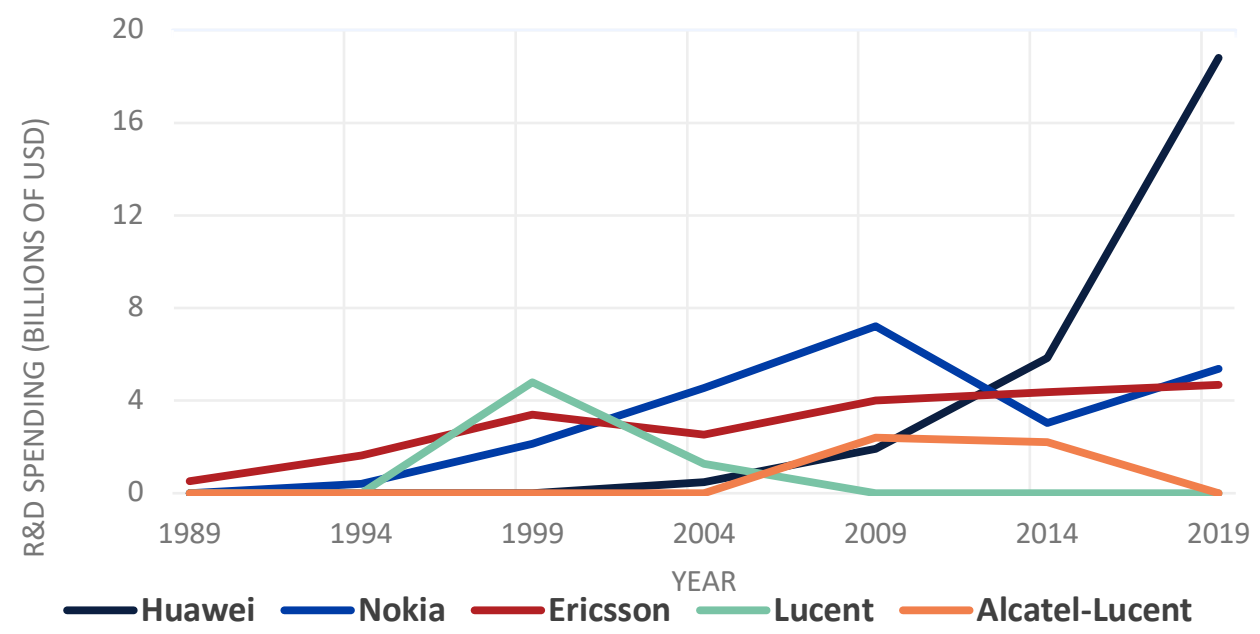

Source: Company Annual Reports. ${ }^{110}$ 
Figure 5: R\&D Personnel at Selected Telecom Firms

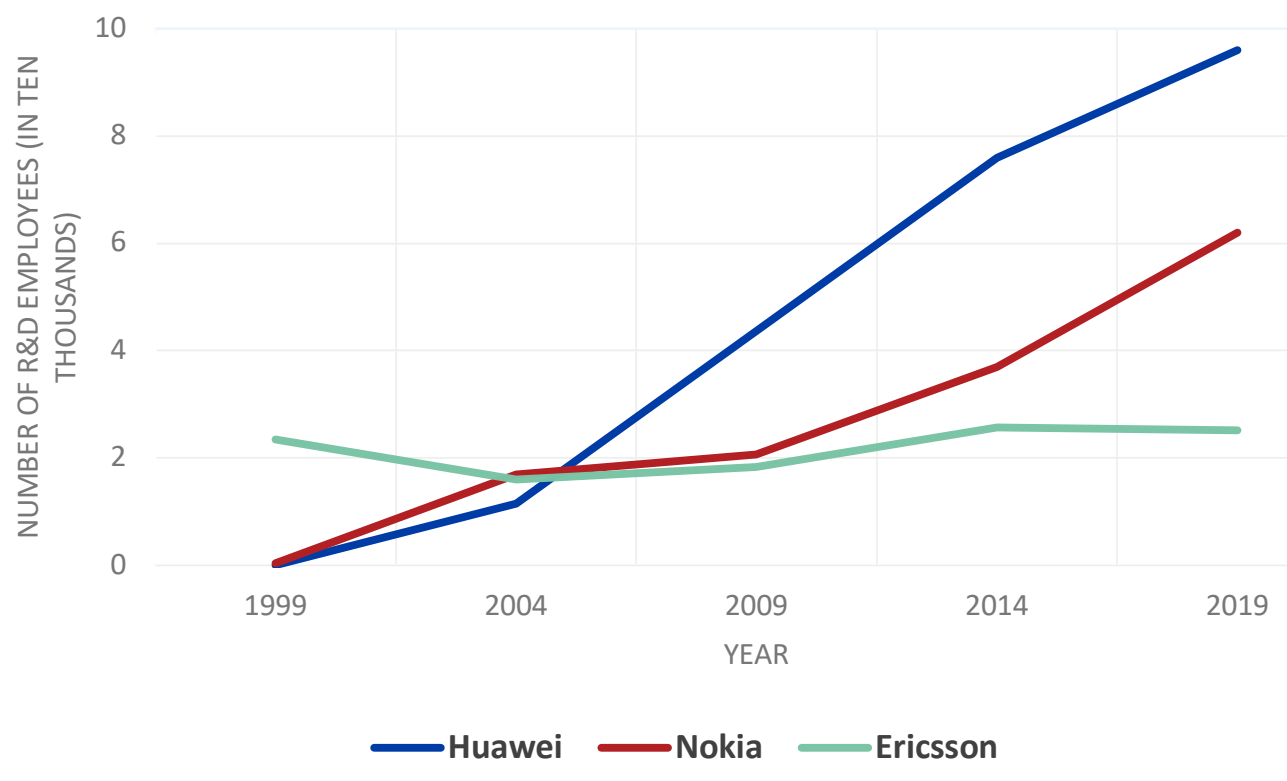

Source: Company Annual Reports. ${ }^{111}$

Parallel to the decline of the U.S. telecommunications equipment firms, Bell Labs experienced a slow decline that further hampered private-sector efforts to continue to push forward advancements in the industry. ${ }^{112}$ Following the dissolution of the AT\&T monopoly, a significant number of the Labs' employees went to a new R\&D organization, Bellcore, which was established to serve the research needs of the RBOCs. ${ }^{113}$ As AT\&T increasingly faced stiff competition, it was forced to downsize the Labs to compensate, both in terms of its scope and its personnel. ${ }^{114}$ This led the Labs to shed even more talented researchers, who left for Bellcore or academia, or were drawn by the allure of new ventures in Silicon Valley. ${ }^{115}$ With AT\&T's reduced scope, shorter time horizons, and increased competition, "unfettered research"—as the Labs called the pursuit of basic research-was no longer in the firm's interest. $^{116}$

The Labs lost even more personnel when AT\&T separated Western Electric into the new Lucent, which retained the Bell Labs name for its R\&D department. ${ }^{117}$ The new Bell Labs then suffered much the same fate as its new parent company during the early to 
mid-2000s. ${ }^{118}$ By the time Lucent merged with French firm Alcatel, the Labs had downsized significantly and had become much more pragmatic to support its parent company's efforts to cope with the increased competition in the telecommunications market. ${ }^{119}$ While persevering as an R\&D entity to support its parent firm's-now Nokia-efforts, its reduced scope, personnel, and resources significantly hampered its ability to continue to develop the breakthroughs for which it had become famous. ${ }^{120}$

Jon Gertner, author of The Idea Factory and numerous articles on R\&D centers at major Silicon Valley companies, highlighted that while many corporate labs continue to conduct cutting-edge research, the focus of that work has fundamentally shifted compared to their twentieth century predecessors. ${ }^{121}$ Many of the United States' leading corporate labs are attached to internet or computer companies, such as Google, IBM, and Microsoft. ${ }^{122}$ For U.S. firms that are key players in the telecommunications industry, such as Apple or Google, their efforts are largely focused on consumer products, cloud services, and software, rather than the enterprise hardware that Huawei offers. ${ }^{123}$ Therefore, despite some of these firms' leading research and advancements in their respective fields, the United States did not have a corporate-or federal lab-that could effectively replace the R\&D conducted by Bell Labs in telecommunications equipment. ${ }^{124}$

Additionally, many corporate labs exist under more restricted funding sources and shorter timelines as compared to their twentieth century predecessors. ${ }^{125}$ Gertner noted that the average timeline given to research projects at many Silicon Valley R\&D centers is two to three years, with the Watson supercomputer being given an uncommon five years. ${ }^{126}$ These timelines are probably sufficient for products aimed at the consumer market but do not allow enough time for products that are aimed at leading generational changes that occur once a decade, as is the case for wireless communications. ${ }^{127}$

Furthermore, fundamental changes in how U.S. corporations operate inhibited the types of long-term investments necessary for sustained competitiveness and innovation in the telecommunications industry. Changes in corporate and 
government policies—such as tax policies, laws on corporate reporting requirements, and legal frameworks governing directors and shareholders, among others-in the 1980 s contributed to increased pressure on firms to maximize short-term earnings and share prices over investments in physical assets, constraining telecommunications firms' efforts to focus on long-term growth. ${ }^{128}$ For an industry, like telecom equipment, that is defined by generational updates that occur over 10 to 15 years, prioritizing short-term profits inhibits the type of R\&D investments that are necessary for preserving competitiveness and innovation. ${ }^{129}$ Industry experts have highlighted the pressure on executives for short-term profits as inhibiting innovation and have called for modernizing the corporate tax system, changing government policies to incentivize long-term productivity growth and global competitiveness, and aligning public policy and corporate governance protocols to facilitate companies' and investors' focus on long-term investment. ${ }^{130}$ Government policies, while not the sole drivers of corporate behavior, can help ameliorate executives' incentives to focus on short-term bottom lines at the expense of riskier and long-term R\&D projects. Conversely, they can also exacerbate short-termism which highlights again the importance of holistic policy approaches to technology development. In this particular case, the confluence of different policies, changing priorities, and new global actors had unintended consequences on a national security critical technology.

Figure 6: Key Drivers for Collapse of the U.S. Telecom

\section{Equipment Industry}

Decline in private-sector R\&D spending

Restricted private-sector funding and development timelines

Lack of federal government prioritization

Avoidance of geopolitical competition in strategic technologies

Federal government aversion to industrial policy

Division of responsibility between economic and security-

focused organizations

Center for Security and Emerging Technology | 27 
The Huawei-China Success Story: From Small

Beginnings to Global Powerhouse: The Power of National Champions

As the United States allowed its telecommunications industry to atrophy, China made information and communications technology a national priority and Chinese firm Huawei used long-term planning, government assistance, a willingness to serve underdeveloped markets, and intellectual property (IP) theft to grow dramatically to its current position as a global leader. ${ }^{131}$ Beijing's ability to not only provide Huawei a guaranteed market share of the world's biggest mobile market—but protect it and restrict competition - gives it a massive advantage over its competitors and allowed the firm to emerge as a developer of novel products for $5 \mathrm{G}$ networks and not just a systems integrator. ${ }^{132}$ China's 4G mobile equipment market accounts for around 40 percent of the total global market. ${ }^{133}$

The Chinese government used a comprehensive support strategy to fuel Huawei's growth. ${ }^{134}$ This mix includes Foreign Ministry support, moves to influence standard setting bodies, market access restrictions, support through state-sponsored S\&T programs, and low interest loans as part of aid packages. ${ }^{135}$ This web of support goes far beyond traditional industrial policies seen in Europe and other parts of Asia and represents an alternative blueprint for the development of other emerging technologies and industries. It also highlights the shortcomings that short-term stock-price driven growth has for national security. ${ }^{136}$ 
Figure 7: Rise of Huawei

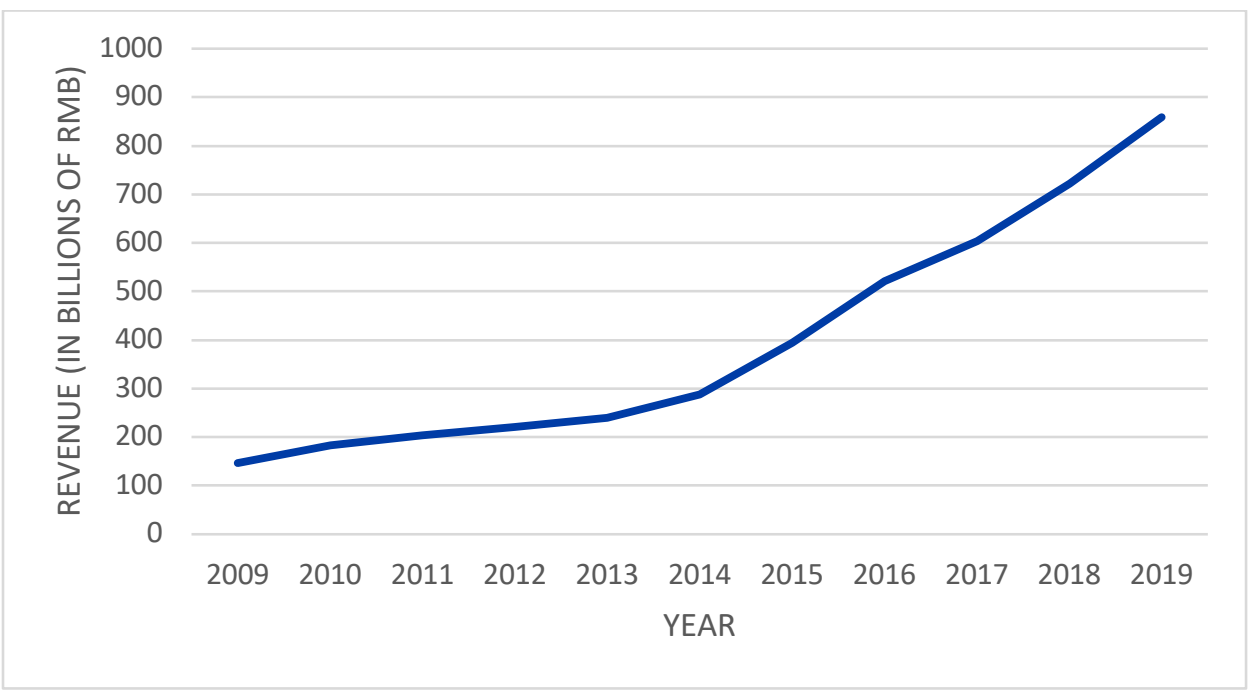

Source: Statista. ${ }^{137}$

Huawei was established in 1987 in the Shenzhen Special Economic Zone by former military engineer, Ren Zhengfei, and began as a reseller for telecommunication devices, leveraging China's expanding demand for telecommunications equipment. ${ }^{138}$ Despite a built-in preference for incumbent domestic firms, the burgeoning demand and knowledge spillover allowed latecomers like Huawei to break into the Chinese market. ${ }^{139}$ Huawei utilized this knowledge spillover and reverse engineering of both Chinese and foreign equipment to develop in-house capabilities to establish a foothold in rural areas and roll out indigenous digital switches. ${ }^{140}$

The arrival of $2 \mathrm{G}$ wireless telecommunications networks lowered prices for subscription services and mobile handsets, increasing demand for $2 \mathrm{G}$ infrastructure equipment. ${ }^{141}$ Huawei established $2 \mathrm{G}$ mobile network technologies R\&D teams as early as 1996, anticipating this demand. ${ }^{142}$ In 1996, Huawei won its first contract outside of mainland China for a switching system for a fixed-line network belonging to Hong Kong's Hutchison Telecommunications. ${ }^{143}$ 
Huawei began expanding to many other markets. In 1997, Huawei formed its first international joint venture (JV) with Russian Telecom. ${ }^{144}$ In 1998, Huawei became the largest provider of certain network equipment in Kenya. ${ }^{145}$ By 2005, Huawei had entered the Latin American market with a RMB 30 million investment in a JV in Brazil. ${ }^{146}$ Huawei expanded its business in emerging markets by establishing job-generating training centers; by 2001, Huawei had functioning centers in Angola, Egypt, and Nigeria. ${ }^{147}$

Despite some success, Huawei initially struggled to compete with foreign firms, which benefitted from experience and resources to compete with Huawei's low prices. ${ }^{148}$ The company underwent restructuring to implement its strategic decision to focus on next generation technology and to better position it to compete in the long-term against foreign competitors, including by expanding its $R \& D$ investments and leveraging government subsidies and support. ${ }^{149}$ During the $2 \mathrm{G}$ to $3 \mathrm{G}$ transition, Huawei began to establish itself as an international player in standards development. ${ }^{150}$ Huawei invested RMB 4 billion in $3 \mathrm{G}$ and hired 3,500 R\&D personnel. The firm also tackled three $3 \mathrm{G}$ standards to further cement its growing role. ${ }^{151}$

Huawei developed partnerships with various European and U.S. firms during the late 1990s and early 2000s, including JVs with AT\&T, Intel, Lucent, Nokia, and Texas Instruments. ${ }^{152}$ Huawei also won contracts with Telefonica and Vodafone during this period. By the early 2000s, Huawei established 10 R\&D centers with European and U.S. partners. ${ }^{153}$

By the time of the $3 \mathrm{G}$ to $4 \mathrm{G}$ transition, Huawei was a recognized player in international standardization bodies; the $3^{\text {rd }}$ Generation Partnership Project approved 665 4G proposals from Huawei, approximately one-fourth of the total. Huawei also secured approximately 50 percent of the 4G LTE market, largely in emerging economies. ${ }^{154}$ For the $4 \mathrm{G}$ to $5 \mathrm{G}$ transition, Huawei is likely the largest player among its three competitors-Ericsson, Nokia, and Samsung. Huawei's prices are typically at least 30 percent lower than those of its competitors, benefitting from generous Chinese government direct and indirect subsidies. ${ }^{155}$ 


\section{Chinese Government Support}

Although Huawei's market-seeking strategy and solid R\&D base were all elements that contributed to its success, Chinese government industrial policies and procurements were largely responsible for its accelerated and market-distorting growth. ${ }^{156^{*}}$

Chinese government national plans and industrial policies, including the various Five-Year Plans, the National Medium- and Long-Term Program for S\&T Development (2006-2020), the Made in China 2025 program, and others have consistently emphasized national development in the telecommunications industry. ${ }^{157}$ Huawei has benefitted significantly under the various national plans, through access to financing, subsidies, diplomatic support, and other forms of assistance from the Chinese government. ${ }^{158}$ In 2019, Beijing added Huawei to its National Al Team to focus on software and hardware, "an endorsement that carries both national and local government support...[and] access to regional projects and related public data resources." 159

A recent study by the Center for American Progress highlights that Beijing's support for Huawei shifted over the course of the firm's development, starting with government efforts to aid the firms' acquisition of technical know-how from firms abroad including Europe, Japan, and the United States, and break into the market. ${ }^{160}$ During this phase, which the study corresponds with the time period ranging from 1988 to 2008, Huawei depended heavily on direct subsidies to address its lack of significant revenues. ${ }^{161}$ During this period, Huawei adopted a business strategy that revolved around securing Chinese government contracts and

\footnotetext{
* While some scholars believe that the Chinese government's support for its industries decreases overall innovation as it is at odds with long-time assessments regarding the importance of market-driven competition (see Rob Atkinson's January 2020 report titled “Innovation Drag: China's Economic Impact on Developed Economies") we assess that in this case, as in others with the same demonstrated characteristics, government support supported the growth and quality of Huawei products. This will increasingly necessitate the reevaluation of how "success" is judged when we examine a non-market economy.
} 
support, reportedly receiving $R \& D$ subsidies through various state programs, including the National High-tech R\&D Program and the National Basic Research Program. ${ }^{162}$ By the end of 1999, Huawei became the most profitable telecom equipment firm in China, largely possible through major contracts with state-owned China Telecom and China Mobile. ${ }^{163}$ This direct support allowed Huawei to secure 10 percent of the global mobile wireless infrastructure market by the mid-2000s. ${ }^{164}$

As Huawei's revenues increased, the firm continued to receive some direct R\&D subsidies_-about $\$ 1.2$ billion over the last five years. ${ }^{165}$ However, indirect subsidies increasingly became the core pillar of Huawei's government assistance, specifically a secure market, state-backed loans, and export financing. ${ }^{166}$

Additionally, Huawei continues to receive support from China's state-controlled banks. ${ }^{167}$ The banks have reportedly provided Huawei, as recently as 2019 , with loans to fund operational costs. 168 These banks have also provided Huawei's customers with billions of dollars to purchase Huawei equipment, in many cases allowing the firm to underbid competitors by significant margins. ${ }^{169}$

Chinese policy banks can provide loans with relatively low interest rates while delivering financing in advance, enabling Huawei's customers to launch projects without dipping into their own cash reserves. ${ }^{170}$

The aforementioned study found that Africa received the largest share of state-backed loans to purchase Huawei equipment, with 57 loans totaling $\$ 4.7$ billion, followed by Europe, Asia, South America, North America, the Middle East, and Oceania, for a total of 99 loans worth approximately $\$ 14.8$ billion. ${ }^{171}$

Since 2015, Huawei's sales of telecommunications network equipment has been included in China's Digital Silk Road, a subset of the Belt and Road Initiative (BRI), which aims to "enhance digital connectivity abroad, extend [China's] influence, and further China's ascendance as a technological superpower." ${ }^{172}$ Huawei's overseas projects included as part of the DSR, and the broader BRI, are eligible for substantial support from state entities. ${ }^{173}$ 
Additionally, Beijing has also provided Huawei intangible support by supporting the firm through diplomatic efforts and promoting the firm as a national champion. ${ }^{174}$ In 1996, Beijing named it a national champion and began explicitly supporting the domestic telecommunications industry from foreign competition. ${ }^{175}$ Beijing has also used its diplomatic heft to influence international standardization bodies to adopt standards developed by Chinese telecom firms. ${ }^{176}$ Beijing positions current and former Chinese telecom officials into the bodies to promote Chinese standards, supports private firms' participation in the bodies, and orders those firms to vote together to support Chinese national interests, efforts which have swayed $5 \mathrm{G}$ standardization decisions in Huawei's favor. ${ }^{177}$ 


\section{Intellectual Property Theft}

Beyond more traditional forms of support from the Chinese government, Huawei has also benefitted during its rise from the business environment fostered by Beijing that normalized technology transfer from foreign firms. ${ }^{178}$ The Section 301 report produced by the Office of the U.S. Trade Representative (USTR) in 2018 found that the Chinese government, through market access and foreign investment restrictions, cyber espionage, and discriminatory licensing and legal requirements, to require or pressure U.S. firms to transfer technology and IP to Chinese firms. ${ }^{179}$ Similarly, a 2012 report by the U.S. House of Representatives Permanent Select Committee on Intelligence found that Huawei "has purposely used and marketed patented products of other companies" and "has exhibited a pattern of, at the very last, reckless disregard for the intellectual property rights of other entities." ${ }^{180}$

In addition to Huawei's reported pattern of disregard for IP rights, the firm was indicted numerous times since 2003 for direct IP theft. In 2003, Cisco Systems claimed Huawei stole networking equipment software, stating that complete copies of text strings from Cisco's source code had been used in various Huawei products without a licensing agreement. ${ }^{181}$ In March 2003, Huawei admitted that an employee copied 2 percent of the router operating software. ${ }^{182}$ In June 2003, the Eastern District of Texas ruled that Huawei could no longer sell the products included in Cisco's claim. ${ }^{183}$ However, in the same month, Huawei established a JV with 3Com, which intervened in the case and asked the court to declare that products made by the JV were licit and did not engage in IP theft. ${ }^{184}$ Analysts conclude that 3 Com supplied its source code in place of Cisco's so that Huawei, and in turn the JV, avoided any significant costs. ${ }^{185}$

A Wall Street Journal investigation that reviewed 10 cases in U.S. federal courts and conducted dozens of interviews "suggest [that] Huawei had a corporate culture that blurred the boundary between competitive achievement and ethically dubious methods of pursuing it." ${ }^{186}$ One of these cases alleges that between 2012 and 2014, Huawei conspired to steal trade secrets from T-Mobile, 
including the firm's proprietary robotic phone testing system Tappy. ${ }^{187}$ A separate case alleges that since 2000, Huawei has sought to grow its business through the "deliberate and repeated misappropriation of IP" of U.S. companies. ${ }^{188}$ Huawei is charged with using proxies, confidentiality and partnership agreements to acquire this IP. ${ }^{189}$ In a specific allegation, Huawei is accused of creating a bonus program to reward employees who "obtained confidential information from competitors." 190

Beyond the cases mentioned above, the nature of technology competition with China and U.S. firms' desire for access to the Chinese market create an incentive structure to dissuade U.S. companies from seeking redress in court. ${ }^{191}$ The USTR report highlighted that "US companies...fear that they will face retaliation or the loss of business opportunities if they come forward to complain about China's unfair trade practices." ${ }^{192}$ Additionally, U.S. companies may have avoided filing complaints in U.S. courts because the financial costs of pursuing a civil case against Huawei would stand no chance of recovering the stolen IP. As is the situation in the aforementioned Cisco case, once Huawei acquired the source code, they were able to find legal loopholes to avoid costs. ${ }^{193}$ 


\section{G Technology Characteristics}

This study highlights that there were certain characteristics of 5G development that China leveraged, exploited, and supported to take the lead in this key technology. They include the need for long term investments, small profit margin industries, support for companies through longer time horizons and the merging of national priorities with commercial priorities. Highlighting these characteristics and the tools that the U.S. government has successfully used in the past to support technology development can be used as a road map for strategies for virtualized 5G networks and other critical and emerging technologies.

First, $5 \mathrm{G}$ equipment is the foundational equipment that benefits not only one company but will spur future industries. It required a longer time horizon than most companies have and required a large upfront R\&D investment. For example, Huawei claims that from 2009 to 2013, it spent more than $\$ 600$ million in 5G-related R\&D and an additional \$1.4 billion in 2017 and 2018. ${ }^{194}$ The requirement for significant $R \& D$ expenditures positioned Huawei to take a lead because of the various direct and indirect subsidies the Chinese Government provided it. ${ }^{195}$

Second, the small profit margins for $5 \mathrm{G}$ telecommunications equipment did not provide significant incentives for technology leaders, such as Amazon, Apple, or Google-firms with some presence in wireless communications or enterprise technology-to enter the market. In contrast, Huawei's guaranteed revenue from the domestic China market and export subsidies allowed the firm to expand its market share and invest in long-term growth while maintaining profits. ${ }^{196}$

Third, the longer time horizons necessary for advancements in 5G equipment ran against the trend within the U.S. private sector to focus on projects with shorter-term returns. U.S. technology firms typically operate with three- to five-year horizons for $R \& D$ projects, limiting their ability to devote significant resources to a large undertaking like developing equipment for $5 \mathrm{G}$ telecommunications networks with horizons closer to a decade. ${ }^{197}$ 


\section{Historically-Deployed Technology Development Tools}

The United States, Japan, South Korea, Taiwan, and countries in Europe have deployed a range of tools to successfully promote the development of technologies deemed critical for economic or national security that could have cross-applicability to telecommunications equipment and other emerging technologies. First and foremost, Washington has set ambitious technology development goals to marshal the efforts of private industry toward a national priority, and used export controls and other restrictions to prevent the transfer of technologies to strategic competitors and adversaries alike. One example is former Operation Warp Speed - the federal effort to speed development of a COVID-19 vaccine-which facilitated two U.S. firms' efforts to bring vaccines with 95 percent efficacy to market in under a year. Pfizer, despite deciding to fund its R\&D efforts itself, received a nearly $\$ 2$ billion order for 100 million doses of its vaccine in July 2020 from Washington-five months before seeking emergency approval from the U.S. Food and Drug Administration. Similarly, Moderna received a $\$ 2.5$ billion subsidy for its efforts from the program. ${ }^{198} \mathrm{Dr}$. Anthony Fauci highlighted, in a recent editorial, the crucial role that public funding of health R\&D played in facilitating companies' ability to bring efficacious COVID-19 vaccines to market in under a year, emphasizing the role of National Institutes of Health funding for the underlying technologies. ${ }^{199}$ Other examples of Washington's use of its powers to promote and/or protect critical technology sectors include:

1. R\&D Funding: From 1990 to 2003 , the U.S. government spent approximately $\$ 2.7$ billion to sequence the human genome as part of the Human Genome Project. ${ }^{200}$ That initial $R \& D$ investment laid the groundwork for U.S. private-sector DNA sequencing firms, such as llumina and ThermoFisher, to expand; by November 2020, the leading U.S. firms were valued at approximately $\$ 323.8$ billion. ${ }^{201}$

2. Corporate Tax Incentives: The U.S. government, through the federal R\&D Tax Credit, allows startups and small businesses to qualify for up to $\$ 1.25$ million to offset a portion of their annual payroll taxes. ${ }^{202}$ Industry experts have 
called for additional incentives to be built into the U.S. tax code to incentivize long-term R\&D investments. ${ }^{203}$

3. Public Procurement: The U.S. government has used the power of federal procurement dollars to promote the development of nascent industries and help them reach economies of scale and commercialize their products. U.S. Air Force and NASA procurement of early integrated circuits for the Minuteman II ICBM and the Apollo program during the 1960s drove improvements in processing power and reductions in production costs, facilitating the industry's commercialization. ${ }^{204}$

4. Talent Development: The U.S. government has supported the education of human capital to bolster technology development efforts. As part of the Space Race, the U.S. government implemented a series of changes to public education to emphasize science and mathematics and hands-on laboratory experience, including through the National Defense Education Act of 1958 and National Science Foundation investments in teacher development. ${ }^{205}$

5. Tech Alliances: The U.S. government has signed collaborative agreements with like-minded countries to govern the protection of and encourage the development of critical technologies. ${ }^{206}$ In 2020, the U.S. and UK governments signed an agreement to cooperate on R\&D of artificial intelligence. ${ }^{207}$

6. Export Financing: The U.S. Export-Import Bank has long provided loans for foreign airlines to purchase U.S. commercial aircraft, helping domestic producers compete with the rise of Airbus during the 1970s and positioning Boeing - the largest U.S. exporter by value - to compete with the Commercial Aircraft Corporation of China (COMAC), once its planes enter production. ${ }^{208}$ 


\section{Lessons from the Huawei Moment}

The Huawei case study is in some ways the canary in the coal mine for emerging technologies and an illustration of what can happen to U.S. competitiveness when China's companies do not have to base decisions on market forces. The early stages of growth for knowledge-based industries will produce the critical foundation for future trade and in some of these areas the first-mover advantage may prove too much for the fast-follower to overcome.

The Huawei example illustrates that when it comes to technologies which the Chinese government considers critical, it is willing to use a wide range of government powers and resources to ensure that Chinese companies dominate foreign competition. While this paper does not assume which technologies China will choose to champion, the Huawei example highlights the approaches and levers that the Chinese government is likely to employ. We have organized these under the themes below. These can be used to develop indicators that China is seeking to dominate a particular critical technology. These can also be used to think through potential Chinese actions for any technology sectors the U.S. may be planning to protect.

\section{Strategic Priority for the Chinese Government}

The trajectory of Huawei and the development of $5 \mathrm{G}$ makes clear that in areas that involve technology and industries that the Chinese government has made a priority-through plans and policies-it will step in to ensure that it achieves its goals whether it adheres to global norms or not. ${ }^{209}$ Decisions are not made based on commercial viability alone and there is willingness to accept inefficiency. ${ }^{210}$ This enables Chinese firms to invest in areas that others, without sustained funding or state support, do not because they do not have to have an immediate commercial application. ${ }^{211}$ This allows China's companies to undercut and choke out the competition-as seen with Huawei. ${ }^{212}$ 


\section{Use All Facets of China's S\&T Infrastructure}

China uses a wide range of actors working in unison to meet a common goal-putting individual foreign companies in competition with the Chinese government. ${ }^{213}$ This is not to imply that there is one big "puppet-master" in Beijing but that China's efforts include a wide range of actors from academics, small business in the United States, and businesses in China that are often either stateowned enterprises or state-supported. ${ }^{214^{*}}$ This complicates any mitigation strategies because of the use of seemingly legitimate organizations that are being used to serve the Chinese government. $^{215}$

\section{Promise of the China Market}

The lure of the China market looms large in U.S. companies' willingness to seek damages in disputes with national champions. ${ }^{216}$ The United States has, up until now, made the assumption that China will acquiesce to global norms of trade and research. ${ }^{217}$ It has further assumed that commercial entities were competing on a fair and level playing field where U.S. firms are playing by the same rules as those from China. ${ }^{218}$ These assumptions have undercut U.S. competitiveness by forcing U.S. firms to compete by themselves against the Chinese state. ${ }^{219}$

\section{Plausible Deniability}

While some of the support given to Huawei has clear violations of law, policies, or administrative rules, many of them live in the "grey" area or offer China plausible deniability because of the web of affiliations and obfuscation of financial ties. ${ }^{220}$ Tie this together with computer network exploitation, as well as influence campaigns that push the "win-win" of these deals, and attribution is often hard to establish and victim companies often do not speak out. ${ }^{221}$

\footnotetext{
* It is important to highlight that in addition to China's state-owned enterprises (SOEs), the CCP supports "private" businesses in ways that are hard to imagine in the United States and Europe. These include a wide range of industries and are even part of the "innovation" plans of cities and provinces.
} 


\section{Build Capacity for the Future}

China's support for emerging and foundational technologies often unfolds over time-putting in place the building blocks of a specific industry. ${ }^{222}$ While in some cases individual companies do benefitsuch as Huawei-China's S\&T infrastructure overall benefits from these developments and the benefit grows over time as Chinese entities are able to capitalize on the information, technology, or skillset that has been acquired and the state support they receive. ${ }^{223}$ 


\section{Conclusion}

This study concludes that the last 20 years highlight various key trends that have led to the decline and disappearance of the U.S. telecommunications equipment industry and the rise of that of China. Moving forward, the characteristics of $5 \mathrm{G}$ and the historic trends that have been identified have broader applicability beyond just 5G. As Washington discusses how best to support development efforts in emerging technologies, with proposals ranging from expanding the budgets for U.S. R\&D agencies, exploring export subsidies through the Export-Import Bank and the new International Development Finance Corporation, and bolstering STEM education to develop the next-generation of S\&T talent, this study argues for a focus on those technologies that are most at risk of foreign adversarial competition, and deployment of a comprehensive strategic plan. The characteristics of $5 \mathrm{G}$ that were highlighted have broader applicability to other technologies that, without efforts to adjust the market incentives, are likely to succumb to similar predicaments for the United States.

One challenge is that in the early stages these new technologies often have not yet produced tradeable goods, requiring remedies that target these technologies at earlier points in their development than export controls or tariffs. As a result, traditional trade remedies such as tariffs and trade sanctions probably will be ineffective at correcting imbalances in high-tech industries that rely on know-how and expertise and will also have limited impact on major national initiatives, including Made in China 2025. As such, further study into the applicability of these characteristics to other emerging technologies may prove useful in helping policymakers prioritize their efforts to those key foundational areas that will have outsized impact on the future. The ultimate lesson from past successes, 5G development, and Operation Warp Speed is that the U.S. government and like-minded allies have tools that can be used to foster the development of emerging technologies and that they should not be afraid to take a proactive approach to foster the building blocks of future discovery and the national innovation base. 
CSET is working on upcoming projects that will explore how the tools the U.S. government has in its arsenal-both carrots and sticks - can be deployed to support the health and growth of the U.S. national innovation base. 


\section{Authors}

Alexander Rubin is a student research analyst with CSET. He is currently pursuing a master's degree at Georgetown University's Center for Security Studies with a concentration in technology and security.

Alan Omar Loera Martinez is an Archer fellow, currently at the University of Texas at El Paso.

Jake Dow works in geopolitical advisory consulting, focusing on the nexus of technology and national security policy. He holds an MPhil from the University of Cambridge.

Anna Puglisi is a senior fellow with CSET. She previously served as the national counterintelligence officer for East Asia, and is a contributing author to China's Quest for Foreign Technology: Beyond Espionage (Routledge, 2020) and coauthor of Chinese Industrial Espionage (Routledge, 2013).

\section{Acknowledgments}

For feedback and assistance, we would like to thank H.R. McMaster, Matthew Turpin, William Hannas, Anne Marie Knott, Lindsay Gorman, Emily Weinstein, Ryan Fedasiuk, and Shelton Fitch. A special thanks to Jon Gertner for his insights on Bell Labs and the Silicon Valley R\&D model discussed in this report.

\section{(c) $(1)(9)$}

(c) 2021 by the Center for Security and Emerging Technology. This work is licensed under a Creative Commons Attribution-Non Commercial 4.0 International License.

To view a copy of this license, visit https://creativecommons.org/licenses/by-nc/4.0/. 


\section{Endnotes}

${ }^{1}$ Robert D. Atkinson, "Who Lost Lucent?: The Decline of America's Telecom Equipment Industry," American Affairs 4, no. 3 (2020), https://americanaffairsjournal.org/2020/08/who-lost-lucent-the-decline-ofamericas-telecom-equipment-industry/; Melanie Hart and Jordan Link, There Is a Solution to the Huawei Challenge, Center for American Progress (2020), https://cdn.americanprogress.org/content/uploads/2020/10/13153542/Solutionto-Huawei-Challenge-NEW.pdf?_ga=2.125289935.416489626.1605976123340138231.1605976123; Galal and O'Halloran, The Impact of 5G: Creating New Value across Industries and Society.

2 Jon Gertner, The idea factory : Bell Labs and the great age of American innovation (New York: Penguin Press, 2012).

${ }^{3}$ Jake Dow, "Assessing Determinants of US Policy Towards China's 21st Century Rise in Telecommunications Infrastructure" (MPhil in International Relations and Politics University of Cambridge, 2020); Atkinson, "Who Lost Lucent?: The Decline of America's Telecom Equipment Industry."

${ }^{4}$ Ashish Arora, Sharon Belenzon, and Andrea Patacconi, Killing the Golden Goose? The Decline of Science in Corporate R\&D, National Bureau of Economic Research (2015), https://www.nber.org/papers/w20902.pdf.

${ }^{5}$ Hart and Link, "There Is a Solution to the Huawei Challenge."

${ }^{6}$ Ibid.

7 Ibid.; USTR, Findings of the investigation into China's acts, policies, and practices related to technology transfer, intellectual property, and innovation under Section 301 of the Trade Act of 1974, (Washington, D.C. 2018); Gertner, The idea factory: Bell Labs and the great age of American innovation; Atkinson, "Who Lost Lucent?: The Decline of America's Telecom Equipment Industry."; Hart and Link, There Is a Solution to the Huawei Challenge.

${ }^{8}$ Gertner, The Idea Factory; "Brownbag with Jon Gertner, author of Idea Factory," interview by Center for Security and Emerging Technology, 2020.

9 Joe Studwell, How Asia Works: Success and Failure in the World's Most Dynamic Region (New York, NY: Grove Press, 2013); Linda Weiss, America Inc.?: Innovation and Enterprise in the National Security State (Ithaca, NY: Cornell University Press, 2014); Marianna Mazzucato, The Entrepreneurial State: Debunking Public vs. Private Sector Myths, Revised Edition ed. (New York: Public Affairs, 2015).

${ }^{10}$ Sharon LaFraniere et al., "Politics, Science, and the Remarkable Race for a Coronavirus Vaccine," The New York Times, November 21, 2020, 
https://www.nytimes.com/2020/11/21/us/politics/coronavirus-

vaccine.html?referringSource=articleShare.

${ }^{11}$ Beethika Khan, Carol Robbins, and Abigail Okrent, "The State of U.S. Science and Engineering 2020" (National Science Foundation | National Science Board, January 15, 2020), https://ncses.nsf.gov/pubs/nsb20201.

12 "The R\&D Tax Credit Is Not Just for Scientists," Alliant Group, accessed 2021, https://www.alliantgroup.com/services/r-d-tax-credit-

2/\#: :text=Startups\%20and\%20small\%20businesses\%20may,of\%20their\%20a nnual\%20payroll\%20taxes.

${ }^{13}$ Mazzucato, The Entrepreneurial State.

${ }^{14}$ Andrew Roush, "How the Space Race Changed American Education," TechNotes, 2019, https://blog.tcea.org/space-race/.

${ }^{15}$ Ashley Gold, "Exclusive: U.S. and U.K. announce Al partnership," Axios, September 25, 2020, https://www.axios.com/ai-partnership-us-uk-831a87a33697-4d58-b2ce-12ac0a38169d.html; U.S. Department of State, "List of Umbrella Science and Technology Agreements," October 28, 2010, https://2009-

2017.state.gov/e/oes/rls/fs/2009/140665.htm\#: :text=Currently\%2C\%20there \%20are\%2045\%20umbrella,taxation\%20issues\%2C\%20and\%20respond\%20t o.

16 "Aviation Exports," Export-Import Bank of the United States, accessed 2020, https://www.exim.gov/policies/aviation-exports; Calum M. Carmichael, "The interdependence of firm and government behaviour: Boeing and Eximbank," Applied Economics 23, no. 1 (1991): 107-112; Fred P. Hochberg, "The Ex-Im Bank Could Be Trump's Best Weapon Against China," Politico, May 24, 2017. https://www.politico.com/magazine/story/2017/05/24/the-ex-im-bank-couldbe-trumps-best-weapon-against-china-215151.

17 "The 5G Economy: How 5G will Impact Global Industries, The Economy, and You."; Galal and O'Halloran, "The Impact of 5G."

${ }^{18}$ Atkinson, "Who Lost Lucent?"; Hart and Link, "There Is a Solution to the Huawei Challenge."

${ }^{19}$ Galal and O'Halloran, "The Impact of 5G"; Simon Hill and Paula Beaton, "5G vs. 4G: How will the newest network improve on the last?" DigitalTrends, February 26, 2021, https://www.digitaltrends.com/mobile/5g-vs4g/\#: : text=With\%204G\%20networks\%2C\%20you're,be\%20processed\%20by \%20the\%20brain; "The Road to 5G: Understanding What's New With the NextGen Network," Samsung Mobile Press, March 3, 2020, https://www.samsungmobilepress.com/featurestories/the-road-to-5gunderstanding-whats-new-with-the-next-gen- 
network\#: :text=It\%20can\%20send\%20data\%20to,kilometer\%20using\%204G \%20networks2.

${ }^{20}$ David E. Sanger and Mary K. Brooks, "Battlefield 5G," The Wilson Quarterly (2020), https://www.wilsonquarterly.com/quarterly/who-writes-therules/battlefield-5g/; Hart and Link, "There Is a Solution to the Huawei Challenge."

${ }^{21}$ Galal and O'Halloran, "The Impact of 5G.”

${ }^{22}$ Clare Duffy, "What is 5G? Your questions answered," CNN, March 6, 2020, https://www.cnn.com/interactive/2020/03/business/what-is-5g/; Qualcomm, "What is 5G?," accessed 2020, https://www.qualcomm.com/invention/5g/whatis-5g.

${ }^{23}$ Duffy, "What is 5G? Your questions answered."; Qualcomm, "What is 5G?."

${ }^{24}$ Duffy, "What is 5G? Your questions answered."; Qualcomm, "What is 5G?."

25 Thomas Donahue, "The Worst Possible Day: US Telecommunications and Huawei," Prism 8, no. 3 (2019),

https://ndupress.ndu.edu/Portals/68/Documents/prism/prism_8-3/prism_8-3.pdf.

${ }^{26}$ Daniel R. Coats, Worldwide Threat Assessment of the US Intelligence Community (Washington, DC: Office of the Director of National Intelligence, 2019), https://www.dni.gov/files/ODNI/documents/2019-ATA-SFR---SSCI.pdf.

27 "The 5G Ecosystem: Risks and Opportunitis for DoD" (U.S. Defense Innovation Board, April 2019), https://media.defense.gov/2019/Apr/03/2002109302/-1/1/0/DIB_5G_STUDY_04.03.19.PDF.

${ }^{28}$ Kiran Stacey, "Pentagon wants open-source 5G plan in campaign against Huawei," The Financial Times, December 22, 2019, https://www.ft.com/content/6863a21a-234a-11ea-92da-f0c92e957a96; U.S. Department of State, "The Clean Network," 2020, https://www.state.gov/theclean-networkl.

${ }^{29}$ Bureau of Industry and Security "Addition of Entities to the Entity List," U.S. Department of Commerce, May 21, 2019, https://www.federalregister.gov/documents/2019/05/21/2019-10616/additionof-entities-to-the-entity-list.

30 U.S. Department of Commerce, "Commerce Addresses Huawei's Efforts to Undermine Entity List, Restricts Products Designed and Produced with U.S. Technologies," May 15, 2020, https://2017-2021.commerce.gov/news/pressreleases/2020/05/commerce-addresses-huaweis-efforts-undermine-entity-listrestricts.html. 
${ }^{31}$ Galal and O'Halloran, “The Impact of 5G."

${ }^{32}$ Roger Entner, "How America's 4G Leadership Propelled the US Economy" (Recon Analytics, 2018), https://reconanalytics.com/2018/04/how-americas-4gleadership-propelled-the-u-s-economy/.

33 "The 5G Economy: How 5G will Impact Global Industries, The Economy, and You."

34 "The 5G Economy."

${ }^{35}$ Weiss, America Inc.?: Innovation and Enterprise in the National Security State.

${ }^{36}$ Gertner, The Idea Factory.

${ }^{37}$ Gertner, The Idea Factory.

${ }^{38}$ Gertner, The Idea Factory.

${ }^{39}$ Gertner, The Idea Factory.

${ }^{40}$ Gertner, The Idea Factory.

${ }^{41}$ Gertner, The Idea Factory.

${ }^{42}$ Mervin J. Kelly, "The Bell Telephone Laboratories: An Example of An Institute of Creative Technology," Royal Society 203, no. 1074 (October 10, 1950):

https://royalsocietypublishing.org/doi/abs/10.1098/rspa.1950.0140.

${ }^{43}$ Gertner, The Idea Factory.

${ }^{44}$ Gertner, The Idea Factory.

${ }^{45}$ Gertner, The Idea Factory.

${ }^{46}$ Gertner, The Idea Factory.

${ }^{47}$ Gertner, The Idea Factory.

${ }^{48}$ Gertner, The Idea Factory.

${ }^{49}$ Gertner, The Idea Factory.

50 "Brownbag with Jon Gertner."

${ }^{51}$ Weiss, America Inc.? 
${ }^{52}$ Mazzucato, The Entrepreneurial State: Debunking Public vs. Private Sector Myths.

${ }^{53}$ Mazzucato, The Entrepreneurial State.

${ }^{54}$ Helen Aki et al., "Where Good Technologies Come From: Case Studies in American Innovation" (Breakthrough Institute, 2010), https://s3.us-east2.amazonaws.com/uploads.thebreakthrough.org/legacy/blog/Case\%20Studies\% 20in\%20American\%20Innovation\%20report.pdf.

${ }^{55}$ Aki et al., "Where Good Technologies Come From."

${ }^{56}$ Aki et al., "Where Good Technologies Come From."

${ }^{57}$ Aki et al., "Where Good Technologies Come From."

${ }^{58}$ Aki et al., "Where Good Technologies Come From."

${ }^{59}$ Weiss, America Inc.?

60 Weiss, America Inc.?

${ }^{61}$ Aki et al., "Where Good Technologies Come From"; Studwell, How Asia Works: Success and Failure in the World's Most Dynamic Region; Thomas R. Howell, Creating Advantage: Semiconductors and Government Industrial Policy in the 1990s, ed. Brent L. Bartlett and Warren Davis (San Jose, CA:

Semiconductor Industry Association, 1992).

${ }^{62}$ Mazzucato, The Entrepreneurial State.

${ }^{63}$ Howell, Creating Advantage: Semiconductors and Government Industrial Policy in the 1990s; Aki et al., "Where Good Technologies Come From."

${ }^{64}$ Robert D. Hof, "Lessons from SEMATECH," MIT Technology Review, July 25, 2011, https://www.technologyreview.com/2011/07/25/192832/lessons-fromsematech/; Christopher S. Yoo, "The Enduring Lessons of the Breakup of AT\&T: A Twenty-Five Year Retrospective," Federal Communications Law Journal 61, no. 1 (2008), https://www.repository.law.indiana.edu/cgi/viewcontent.cgi?article=1514\&conte $\mathrm{xt=fclj;} \mathrm{U.S.} \mathrm{General} \mathrm{Accounting} \mathrm{Office,} \mathrm{Lessons} \mathrm{Learned} \mathrm{From} \mathrm{SEMATECH}$ (1992).

${ }^{65}$ U.S. Department of Commerce, "Commerce Addresses Huawei's Efforts to Undermine Entity List, Restricts Products Designed and Produced with U.S. Technologies."

${ }^{66}$ Atkinson, "Who Lost Lucent?" 
${ }^{67}$ Yoo, "The Enduring Lessons of the Breakup of AT\&T: A Twenty-Five Year Retrospective"; Gertner, The Idea Factory.

${ }^{68}$ Atkinson, "Who Lost Lucent?"

${ }^{69}$ Atkinson, "Who Lost Lucent?"

${ }^{70}$ Atkinson, "Who Lost Lucent?"

${ }^{71}$ Atkinson, "Who Lost Lucent?"

${ }^{72}$ Atkinson, “Who Lost Lucent?"

${ }^{73}$ Atkinson, "Who Lost Lucent?"

${ }^{74}$ William Lazonick and Edward March, "The Rise and Demise of Lucent Technologies," Business History Conference. Business and Economic History On-line: Papers Presented at the BHC Annual Meeting 9 (2011), https://searchproquest-

com.proxy.library.georgetown.edu/docview/896702001?accountid $=11091 \&$ rfr_i d=info\%3Axri\%2Fsid\%3Aprimo.

${ }^{75}$ Lazonick and March, "The Rise and Demise of Lucent Technologies."

${ }^{76}$ Lazonick and March, "The Rise and Demise of Lucent Technologies."

77 Steve Coll, The Deal of the Century: The Break Up of AT\&T (New York, NY: Atheneum, 1986).

${ }^{78}$ Atkinson, "Who Lost Lucent?"; Dow, "Assessing Determinants of US Policy Towards China's 21st Century Rise in Telecommunications Infrastructure."

${ }^{79}$ Atkinson, “Who Lost Lucent?"

${ }^{80}$ Atkinson, “Who Lost Lucent?"

${ }^{81}$ Atkinson, "Who Lost Lucent?"

${ }^{82}$ Atkinson, "Who Lost Lucent?"

${ }^{83}$ Atkinson, "Who Lost Lucent?"

${ }^{84}$ Timothy Fogarty et al., "Inside Agency: The Rise and Fall of Nortel," Journal of Business Ethics 84, no. 2 (2009): 165-187, https://doi.org/10.1007/s10551008-9680-9, https://www-jstororg.proxy.library.georgetown.edu/stable/40294736.

${ }^{85}$ Lazonick and March, "The Rise and Demise of Lucent Technologies." 
${ }^{86}$ Atkinson, "Who Lost Lucent?"

${ }^{87}$ Atkinson, "Who Lost Lucent?"

${ }^{88}$ Atkinson, "Who Lost Lucent?"

${ }^{89}$ Atkinson, "Who Lost Lucent?"

${ }^{90}$ Dow, "Assessing Determinants of US Policy."

${ }^{91}$ George W. Bush, The National Security Strategy of the United States of America (Washington, DC: The White House, September 2002); George W. Bush, The National Security Strategy of the United States of America (Washington, DC: The White House, March 2006); Barack Obama, National Security Strategy (Washington, DC: The White House, May 2010); Quadrennial Defense Review Report (Washington, DC: Department of Defense, February 6, 2006); Quadrennial Defense Review Report (Washington, DC: Department of Defense, February 2010).

92 Dow, "Assessing Determinants of US Policy."

${ }^{93}$ Atkinson, "Who Lost Lucent?"

${ }^{94}$ Dow, "Assessing Determinants of US Policy."

${ }^{95}$ Mike Rogers and C. A. Dutch Ruppersberger, Investigative Report on the US National Security Issues Posed by Chinese Telecommunications Companies Huawei and ZTE (Washington, DC: House of Representatives, October 8, 2012).

${ }^{96}$ Dow, "Assessing Determinants of US Policy"; National Strategy for Critical and Emerging Technologies (Washington, DC: The White House, 2020); US Department of Justice, "The China Initiative: Year-in-Review (2019-20)," November 16, 2020, https://www.justice.gov/opa/pr/china-initiative-yearreview-2019-20.

${ }^{97}$ Dow, "Assessing Determinants of US Policy"; "The National Security Policy Porcess: The National Security Council and Interagency System" (Industrial College of the Armed Forces, National Defense University, 2011), https://issat.dcaf.ch/download/17619/205945/icaf-nsc-policy-process-report$08-$

2011.pdfThe\%20National\%20Security\%20Policy\%20Process:\%20The\%20Nati onal\%20Security\%20Council\%20and\%20Interagency\%20System\#: :text=Sub ordinate\%20to\%20the\%20DC\%20are,agencies\%20rep.

${ }_{98}$ Mazzucato, The Entrepreneurial State; Geoffrey Gertz and Miles M. Evers, "Geoeconomic Competition: Will State Capitalism Win?," The Washington Quarterly 43, no. 2 (2020), https://www.tandfonline.com/doi/full/10.1080/0163660X.2020.1770962; Peter 
A. Hall and David Soskice, Varieties of Capitalism: The Institutional Foundations of Comparative Advantage (Oxford, UK: Oxford University Press, 2001).

${ }_{99}$ Dow, "Assessing Determinants of US Policy."

${ }^{100}$ Robert W. Lucky and Jon Eisenberg, "Renewing US Telecommunications Research" (National Research Council, 2006), https://www.nap.edu/catalog/11711/renewing-us-telecommunicationsresearch.

101 Lucky and Eisenberg, "Renewing US Telecommunications Research."

102 Lucky and Eisenberg, "Renewing US Telecommunications Research."

${ }^{103}$ Dow, "Assessing Determinants of US Policy."

${ }^{104}$ Hart and Link, "There Is a Solution to the Huawei Challenge."

105 "Biggest companies in the world by market capitalization 2020," Statista, May 2020, https://www.statista.com/statistics/263264/top-companies-in-the-worldby-market-capitalization/; Gertner, The Idea Factory; Weiss, America Inc.?.

106 "Biggest companies in the world by market capitalization 2020."

107 “Alphabet Profit Margin 2006-2020," Macrotrends, accessed 2020, https://www.macrotrends.net/stocks/charts/GOOG/alphabet/profit-margins; "Gross Profit Margin for Amazon.com, Inc.," Finbox, 2020, https://finbox.com/NASDAQGS:AMZN/explorer/gp_margin\#: :text=Amazon.com 's\%20gross\%20profit\%20margin,in\%20December\%202019\%20at\%2041.0\% 25; Jeff Horwitz, "Facebook Reports Revenue Growth, Rising Expenses," The Wall Street Journal, January 29, 2020, https://www.wsj.com/articles/facebookreports-25-revenue-growth-in-latest-quarter11580333926\#: :text=And\%20added\%20spending\%20is\%20eating,as\%20a \%20share\%20of\%20revenue; "Microsoft Profit Margin 2006-2020," Macrotrends, 2020, https://www.macrotrends.net/stocks/charts/MSFT/microsoft/profit-margins; "Gross Profit Margin for Apple Inc.," Finbox, 2020, https://finbox.com/NASDAQGS:AAPL/explorer/gp_margin\#: :text=Apple's\%200 perated\%20at\%20median\%20gross,in\%20September\%202019\%20of\%2037. 8\%25; "Huawei Revenue Growth, Profit Margin Drop Sharply in Third Quarter," Caixin, October 23, 2020, https://www.caixinglobal.com/2020-10-23/huaweirevenue-growth-profit-margin-drop-sharply-in-third-quarter-101618102.html; "Ericsson Profit Margin 2006-2020," Macrotrends, 2020, https://www.macrotrends.net/stocks/charts/ERIC/ericsson/profit-margins; "Nokia Profit Margin 2006-2020," Macrotrends, 2020, https://www.macrotrends.net/stocks/charts/NOK/nokia/profit-margins. 
${ }^{108}$ Hart and Link, "There Is a Solution to the Huawei Challenge."

${ }^{109}$ Gertner, The Idea Factory; "Brownbag with Jon Gertner."

${ }^{110}$ Brian Low, "Huawei Technologies Corporation: From Local Dominance to Global Challenge?," Journal of Business \& Industrial Marketing 22, no. 2 (2007), https://pdfs.semanticscholar.org/795b/9862474d89d13116d5d313e471c0a6d 045f2.pdf; Huawei Technologies Co. Ltd., "2009 Year Annual Report," 2010, https://web.archive.org/web/20201217040249/https://www.huawei.com/ucmf/ groups/public/documents/webasset/hw_076948.pdf; Huawei Technologies Co. Ltd., "2014 Year Annual Report," 2015, https://web.archive.org/web/20201217040505/https://www-file.huawei.com//media/corporate/pdf/press-center/mediakit/huawei_annual_report_2014_cn.pdf?la=zh; Huawei Technologies Co. Ltd., "Huawei Investment Holdings Co., Ltd. 2019 Annual Report," 2020, https://web.archive.org/web/20201217035825/http://webcache.googleusercont ent.com/search?q=cache\%3AjaTwWfXq_h0J\%3At.cn\%2FA6Zolj9d+\&cd=7\&hl= en\&ct=clnk\&gl=mx; Harry Bouwman, Christer Carlsson, Joanna Carlsson, Shahrokh Nikou, Anna Sell \& Pirkko Walden, "How Nokia Failed to Nail the Smartphone Market," $25^{\text {th }}$ European Regional Conference of the International Telecommunication Society (ITS), 2014, https://www.researchgate.net/publication/265637998_How_Nokia_Failed_to_N ail_the_Smartphone_Market; Nokia Corporation, "Nokia Annual Report 1999," 2000, https://web.lib.aalto.fi/fi/old/yrityspalvelin/pdf/1999/Enokia.pdf; Nokia Corporation, "Nokia Annual Accounts 2004," 2005, https://www.nokia.com/system/files/files/request-nokia-in-2004-pdf.pdf; Nokia Corporation, "Nokia Annual Accounts 2009," 2010, https://www.nokia.com/system/files/files/request-nokia-in-2009-pdf.pdf; Nokia Corporation, "Nokia in 2014," 2015, https://www.nokia.com/system/files/files/nokia_uk_ar14_full_1.pdf; Nokia Corporation, "Nokia in 2019 Annual Report," 2020, https://www.nokia.com/system/files/2020-

03/Nokia\%20in\%202019\%20annual\%20report_1.pdf; Ericsson, "Annual Report 1994," 1995,

https://www.ericsson.com/48f956/assets/local/investors/documents/financialreports-and-filings/annual-reports/annualreport1994_en.pdf; Ericsson, “Annual Report 1999," 2000, https://www.ericsson.com/48fa73/assets/local/investors/documents/financialreports-and-filings/annual-reports/annua_fullreport_en_1999.pdf; Ericsson, “Annual Report 2004," 2005, https://www.ericsson.com/48f6a1/assets/local/investors/documents/financialreports-and-filings/annual-reports/ericsson_ar2004_complete_en.pdf; Ericsson, "Annual Report 2009," 2010, https://www.ericsson.com/4ac120/assets/local/investors/documents/financialreports-and-filings/annual-reports/ericsson-annual-report2009-en.pdf; Ericsson, "Annual Report 2014," 2015, https://www.ericsson.com/48fb26/assets/local/investors/documents/financial- 
reports-and-filings/annual-reports/ericsson-annual-report-2014-en.pdf;

Ericsson, “Annual Report 2019," 2020,

https://www.ericsson.com/495c1f/assets/local/investors/documents/2019/ericss on-annual-report-2019-en.pdf; William Lazonick and Edward March, "The Rise and Demise of Lucent Technologies," University Library of Munich, April 9, 2010, https://mpra.ub.uni-muenchen.de/22012/1/lazonick-

march_lucent_final_20100410.pdf; Alcatel-Lucent, “2009 Annual Report on Form 20-F," 2010,

https://www.sec.gov/Archives/edgar/data/886125/000130817910000036/alc2 00920f.htm; Alcatel-Lucent, "2014 Annual Report on Form 20-F," 2015, https://sec.report/Document/0001193125-15-103037/.

${ }^{111}$ Low, "Huawei Technologies Corporation: From Local Dominance to Global Challenge?"; Huawei Technologies Co. Ltd., "Huawei Technologies Co. Ltd. 2009 Year Annual Report"; Huawei Technologies Co. Ltd., "2014 Year Annual Report,"; Huawei Technologies Co. Ltd., "Huawei Investment Holdings Co., Ltd. 2019 Annual Report"; Bouwman et al., "How Nokia Failed to Nail the Smartphone Market”; Nokia Corporation, “Nokia Annual Report 1999”; Nokia Corporation, "Nokia Annual Accounts 2004"; Nokia Corporation, "Nokia Annual Accounts 2009"; Nokia Corporation, "Nokia in 2014"; Nokia Corporation, "Nokia in 2019 Annual Report"; Ericsson, "Annual Report 1994"; Ericsson, "Annual Report 1999"; Ericsson, "Annual Report 2004"; Ericsson, "Annual Report 2009," Ericsson, "Annual Report 2014"; Ericsson, "Annual Report 2019"; Lazonick and March, "The Rise and Demise of Lucent Technologies"; Alcatel-Lucent, "2009 Annual Report on Form 20-F"; Alcatel-Lucent, "2014 Annual Report on Form 20-F."

112 Gertner, The Idea Factory.

${ }^{113}$ Gertner, The Idea Factory.

${ }^{114}$ Gertner, The Idea Factory.

${ }^{115}$ Gertner, The Idea Factory.

${ }^{116}$ Gertner, The Idea Factory.

${ }^{117}$ Gertner, The Idea Factory.

118 Gertner, The Idea Factory.

${ }^{119}$ Gertner, The Idea Factory.

${ }^{120}$ Gertner, The Idea Factory.

121 "Brownbag with Jon Gertner"; Gertner, The Idea Factory. 
122 "Brownbag with Jon Gertner"; Gertner, The Idea Factory.

123 "Brownbag with Jon Gertner"; Gertner, The Idea Factory.

124 "Brownbag with Jon Gertner"; Gertner, The Idea Factory.

125 "Brownbag with Jon Gertner."

126 "Brownbag with Jon Gertner."

127 "Brownbag with Jon Gertner."

${ }^{128}$ Atkinson, "Who Lost Lucent?"

${ }^{129}$ Arora, Belenzon, and Patacconi, Killing the Golden Goose? The Decline of Science in Corporate R\&D.

${ }^{130}$ Bill Budinger et al., "American Prosperity Project: A Nonpartisan Framework for Long-term Investment" (The Aspen Institute, December 2016), https://www.aspeninstitute.org/wp-content/uploads/2017/01/AmericanProsperity-Project_Policy-Framework_FINAL-1.3.17.pdf.

${ }^{131}$ Hart and Link, "There Is a Solution to the Huawei Challenge"; Lindsay Maizland and Andrew Chatzky, "Huawei: China's Controversial Tech Giant" (Council on Foreign Relations, August 6, 2020), https://www.cfr.org/backgrounder/huawei-chinas-controversial-tech-giant; Nathaniel Ahrens, "China's Competitiveness: Myth, Reality, and Lessons for the United States and Japan-Case Study: Huawei" (Center for Strategic and International Studies, February 2013), https://csis-websiteprod.s3.amazonaws.com/s3fspublic/legacy_files/files/publication/130215_competitiveness_Huawei_casestudy Web.pdf.

132 Hart and Link, "There Is a Solution to the Huawei Challenge."

${ }^{133}$ Hart and Link, "There Is a Solution to the Huawei Challenge."

${ }^{134}$ Hart and Link, "There Is a Solution to the Huawei Challenge."

${ }^{135}$ Hart and Link, "There Is a Solution to the Huawei Challenge."

${ }^{136}$ Hart and Link, "There Is a Solution to the Huawei Challenge."

137 "Revenue of Huawei 2009-2019," Statista, updated November 24, 2020, https://www.statista.com/statistics/233071/revenue-of-huawei/.

138 Lei Guo, Marina Yue Zhang, Mark Dodgson, David Gann, and Hong Cai, "Seizing Windows of Opportunity by Using Technology-Building and MarketSeeking Strategies in Tandem: Huawei's Sustained Catch-Up in the Global 
Market," Asia Pacific Journal of Management 36, no. 1 (2019). Ahrens, China's Competitiveness: Myth, Reality, and Lessons for the United States and JapanCase Study: Huawei.

${ }^{139}$ Guo, Zhang, Dodgson, Gann, and Cai, "Seizing Windows of Opportunity by Using Technology-Building and Market-Seeking Strategies in Tandem: Huawei's Sustained Catch-Up in the Global Market."

${ }^{140}$ Guo et al., "Seizing Windows of Opportunity."

${ }^{141}$ Guo et al., "Seizing Windows of Opportunity."

${ }^{142}$ Guo et al., "Seizing Windows of Opportunity."

${ }^{143}$ Bruce Gilley, "Huawei's Fixed Line to Beijing," Far Eastern Economic Review (2000).

${ }^{144}$ Guo et al., "Seizing Windows of Opportunity."

145 Guo et al., "Seizing Windows of Opportunity."

${ }^{146}$ Guo et al., "Seizing Windows of Opportunity."

${ }^{147}$ Christine Chang et al., "Huawei Technologies: A Chinese Trail Blazer in Africa," Knowledge at Wharton, April 20, 2009,

https://knowledge.wharton.upenn.edu/article/huawei-technologies-a-chinesetrail-blazer-inafrica/\#: :text=Walk\%20into\%20a\%20bookstore\%20in,with\%20books\%20abo ut\%20Huawei\%20Technologies.\&text=\%E2\%80\%9CHuawei\%20is\%20current ly\%20the\%20number,founder\%20and\%20C.

148 Guo et al., "Seizing Windows of Opportunity."

${ }^{149}$ Guo et al., "Seizing Windows of Opportunity."

${ }^{150}$ Guo et al., "Seizing Windows of Opportunity."

${ }^{151}$ Guo et al., "Seizing Windows of Opportunity."

152 Gilley, “Huawei's Fixed Line to Beijing."

153 Gilley, “Huawei's Fixed Line to Beijing."

${ }^{154}$ Guo et al., "Seizing Windows of Opportunity."

${ }^{155}$ Hart and Link, "There Is a Solution to the Huawei Challenge"; Maizland and Chatzky, "Huawei: China's Controversial Tech Giant"; Ahrens, "China's Competitiveness." 
${ }^{156}$ Ahrens, "China's Competitiveness"; Hart and Link, "There Is a Solution to the Huawei Challenge."

157 The National Medium- and Long-Term Program for Science and Technology Development (2006-2020) (State Council of the People's Republic of China, 2006); Roadmap of Major Technical Domains for Made in China 2025 (The State Strategic Advisory Committee for Building China into a Manufacturing Superpower, 2015); 13th National Five-Year Plan for the Development of Strategic Emerging Industries (State Council of the People's Republic of China, November 2016).

158 Hart and Link, "There Is a Solution to the Huawei Challenge."

${ }^{159}$ Benjamin Larsen, "Drafting China's National Al Team for Governance," New America, November 18, 2019, https://www.newamerica.org/cybersecurityinitiative/digichina/blog/drafting-chinas-national-ai-team-governance/; Sarah Dai, "China adds Huawei, Hikvision to expanded 'national team' spearheading country's Al efforts," South China Morning Post, August 30, 2019, https://www.scmp.com/tech/big-tech/article/3024966/china-adds-huaweihikvision-expanded-national-team-spearheading.

${ }^{160}$ Hart and Link, "There Is a Solution to the Huawei Challenge."

${ }^{161}$ Hart and Link, "There Is a Solution to the Huawei Challenge."

162 Hart and Link, "There Is a Solution to the Huawei Challenge."

${ }^{163}$ Gilley, "Huawei's Fixed Line to Beijing."

${ }^{164}$ Hart and Link, "There Is a Solution to the Huawei Challenge."

165 Hart and Link, "There Is a Solution to the Huawei Challenge."

166 Hart and Link, "There Is a Solution to the Huawei Challenge."

167 Hart and Link, "There Is a Solution to the Huawei Challenge."

168 Hart and Link, "There Is a Solution to the Huawei Challenge."

${ }^{169}$ Hart and Link, "There Is a Solution to the Huawei Challenge."

${ }^{170}$ Hart and Link, "There Is a Solution to the Huawei Challenge."

${ }^{171}$ Hart and Link, "There Is a Solution to the Huawei Challenge."

172 Clayton Cheney, “China's Digital Silk Road: Strategic Technological Competition and Exporting Political Illiberalism," Council of Foreign Relations, September 26, 2019, https://www.cfr.org/blog/chinas-digital-silk-roadstrategic-technological-competition-and-exporting-political; Joshua Kurlantzick, 
"China's Digital Silk Road Initiative: A Boon for Developing Countries or a Danger to Freedom?," The Diplomat, December 17, 2020,

https:/thediplomat.com/2020/12/chinas-digital-silk-road-initiative-a-boon-fordeveloping-countries-or-a-danger-to-freedom/.

${ }^{173}$ Robert Greene and Paul Triolo, "Will China Control the Global Internet Via Its Digital Silk Road?," SupChina, May 8, 2020, https://carnegieendowment.org/2020/05/08/will-china-control-global-internetvia-its-digital-silk-road-pub-81857.

${ }^{174}$ Ahrens, "China's Competitiveness."

${ }^{175}$ Ahrens, "China's Competitiveness."

${ }^{176}$ Hart and Link, "There Is a Solution to the Huawei Challenge."

${ }^{177}$ Hart and Link, "There Is a Solution to the Huawei Challenge."

178 Office of the United States Trade Representative, Findings of the Investigation into China's Acts, Policies, and Practices Related to Technology Transfer, Intellectual Property, and Innovation under Section 301 of the Trade Act of 1974; William C. Hannas and Didi Kirsten Tatlow, China's Quest for Foreign Technology: Beyond Espionage (New York, NY: Routledge, 2020).

179 Office of the United States Trade Representative, Findings of the Investigation into China's Acts.

180 Rogers and Ruppersberger, Investigative Report on the US National Security Issues Posed by Chinese Telecommunications Companies Huawei and ZTE.

181 Jen Lin-Liu, "Huawei-Cisco Tests China's Respect for Property Rights," IEEE Spectrum 40, no. 8 (2003).

182 Lin-Liu, “Huawei-Cisco Tests China's Respect."

${ }^{183}$ Lin-Liu, "Huawei-Cisco Tests China's Respect."

${ }^{184}$ Lin-Liu, "Huawei-Cisco Tests China's Respect."

185 Lin-Liu, “Huawei-Cisco Tests China’s Respect.”

${ }^{186}$ Chuin-Wei Yap et al., "Huawei's Yearslong Rise Is Littered With Accusations of Theft and Dubious Ethics," The Wall Street Journal, May 25, 2019, https://www.wsj.com/articles/huaweis-yearslong-rise-is-littered-withaccusations-of-theft-and-dubious-ethics-11558756858.

187 U.S. Department of Justice, United States of America v. Huawei Device Co., Ltd., and Huawei Device USA, Inc., 2019. 
188 U.S. Department of Justice, United States of America v. Huawei Device Co., Ltd., and Huawei Device USA, Inc., 2019.

189 U.S. Department of Justice, United States of America v. Huawei Device Co., Ltd., and Huawei Device USA, Inc., 2019.

190 U.S. Department of Justice, United States of America v. Huawei Device Co., Ltd., and Huawei Device USA, Inc., 2019.

191 Office of the United States Trade Representative, Findings of the Investigation into China's Acts.

192 Office of the United States Trade Representative, Findings of the Investigation into China's Acts.

${ }^{193}$ Lin-Liu, "Huawei-Cisco Tests China's Respect."

194 “5G, Gear Up," Huawei, accessed 2020,

https://carrier.huawei.com/en/spotlight/5g.

${ }^{195}$ Hart and Link, "There Is a Solution to the Huawei Challenge."

${ }^{196}$ Hart and Link, "There Is a Solution to the Huawei Challenge."

197 "Brownbag with Jon Gertner."

${ }^{198}$ LaFraniere et al., "Politics, Science, and the Remarkable Race for a Coronavirus Vaccine."

199 Anthony S. Fauci, “The story behind COVID-19 vaccines," Science 372, no. 6538 (2021): 109, https://science.sciencemag.org/content/372/6538/109.

200 "Human Genome Project," National Human Genome Research Institute, https://www.genome.gov/human-genome-project/Completion-

FAQ\#: :text=How\%20much\%20did\%20it\%20cost,billion\%20in\%20FY\%20199 $1 \% 20$ dollars.

201 "Company Info," Bloomberg, accessed November 27, 2020, https://www.bloomberg.com/; “Top 10 Gene Sequencing Companies by Revenue," Biospace, November 29, 2019, https://www.biospace.com/article/top10-gene-sequencing-companies-by-revenue/.

202 "The R\&D Tax Credit Is Not Just for Scientists."

${ }^{203}$ Budinger et al., "American Prosperity Project: A Nonpartisan Framework for Long-term Investment."

${ }^{204}$ Mazzucato, The Entrepreneurial State. 
${ }^{205}$ Roush, "How the Space Race Changed American Education."

206 U.S. Department of State, "List of Umbrella Science and Technology Agreements."

207 Gold, "Exclusive: US and UK announce Al partnership."

208 "Aviation Exports"; Carmichael, "The interdependence of firm and government behaviour: Boeing and Eximbank"; Hochberg, "The Ex-Im Bank Could Be Trump's Best Weapon Against China."

${ }^{209}$ Hannas and Tatlow, China's Quest for Foreign Technology: Beyond Espionage; William C. Hannas, James Mulvenon, and Anna B. Puglisi, Chinese Industrial Espionage: Technology Acquisition and Military Modernisation (New York, NY: Routledge, 2013).

${ }^{210}$ Hannas and Tatlow, China's Quest for Foreign Technology; Hannas, Mulvenon, and Puglisi, Chinese Industrial Espionage.

${ }^{211}$ Hannas and Tatlow, China's Quest for Foreign Technology; Hannas, Mulvenon, and Puglisi, Chinese Industrial Espionage.

212 Hannas and Tatlow, China's Quest for Foreign Technology; Hannas, Mulvenon, and Puglisi, Chinese Industrial Espionage.

${ }^{213}$ Hannas and Tatlow, China's Quest for Foreign Technology; Hannas, Mulvenon, and Puglisi, Chinese Industrial Espionage.

${ }^{214}$ Hannas and Tatlow, China's Quest for Foreign Technology; Hannas, Mulvenon, and Puglisi, Chinese Industrial Espionage.

${ }^{215}$ Hannas and Tatlow, China's Quest for Foreign Technology; Hannas, Mulvenon, and Puglisi, Chinese Industrial Espionage.

${ }^{216}$ Hannas and Tatlow, China's Quest for Foreign Technology; Hannas, Mulvenon, and Puglisi, Chinese Industrial Espionage.

${ }^{217}$ Hannas and Tatlow, China's Quest for Foreign Technology; Hannas, Mulvenon, and Puglisi, Chinese Industrial Espionage.

${ }^{218}$ Hannas and Tatlow, China's Quest for Foreign Technology; Hannas, Mulvenon, and Puglisi, Chinese Industrial Espionage.

219 Hannas and Tatlow, China's Quest for Foreign Technology; Hannas, Mulvenon, and Puglisi, Chinese Industrial Espionage.

${ }^{220}$ Hannas and Tatlow, China's Quest for Foreign Technology; Hannas, Mulvenon, and Puglisi, Chinese Industrial Espionage. 
${ }^{221}$ Hannas and Tatlow, China's Quest for Foreign Technology; Hannas, Mulvenon, and Puglisi, Chinese Industrial Espionage.

222 Hannas and Tatlow, China's Quest for Foreign Technology; Hannas, Mulvenon, and Puglisi, Chinese Industrial Espionage.

${ }^{223}$ Hannas and Tatlow, China's Quest for Foreign Technology; Hannas, Mulvenon, and Puglisi, Chinese Industrial Espionage. 